\title{
Seasonal patterns in plankton communities in a pluriannual time series at a coastal Mediterranean site (Gulf of Naples): an attempt to discern recurrences and trends*
}

\author{
M. RIBERA D'ALCALÀ, F. CONVERSANO, F. CORATO, P. LICANDRO, O. MANGONI, \\ D. MARINO, M.G. MAZZOCCHI, M. MODIGH, M. MONTRESOR, M. NARDELLA, \\ V. SAGGIOMO, D. SARNO and A. ZINGONE
}

Stazione Zoologica ‘A.Dohrn’, Villa Comunale, 80121 Napoli, Italy. E-mail: maurizio@szn.it

\begin{abstract}
SUMMARY: The annual cycle of plankton was studied over 14 years from 1984 to 2000 at a coastal station in the Gulf of Naples, with the aim of assessing seasonal patterns and interannual trends. Phytoplankton biomass started increasing over the water column in February-early March, and generally achieved peak values in the upper layers in late spring. Another peak was often recorded in autumn. Diatoms and phytoflagellates dominated for the largest part of the year. Ciliates showed their main peaks in phase with phytoplankton and were mainly represented by small $(<30 \mu \mathrm{m})$ naked choreotrichs. Mesozooplankton increased in March-April, reaching maximum concentrations in summer. Copepods were always the most abundant group, followed by cladocerans in summer. At the interannual scale, a high variability and a decreasing trend were recorded over the sampling period for autotrophic biomass. Mesozooplankton biomass showed a less marked interannual variability. From 1995 onwards, phytoplankton populations increased in cell number but decreased in cell size, with intense blooms of small diatoms and undetermined coccoid species frequently observed in recent years. In spite of those interannual variations, the different phases of the annual cycle and the occurrence of several plankton species were remarkably regular.
\end{abstract}

Key words: Mediterranean Sea, phytoplankton, ciliates, mesozooplankton, seasonal cycle, long term series.

RESUMEN: PATRONES ESTACIONALES EN LAS COMUNIDADES PLANCTÓNICAS EN UNA SERIE TEMPORAL PLURIANUAL EN UNA LOCALIDAD COSTERA DEl MEDITERRÁNEO (Golfo DE NÁPOLES): Un INTENTO DE DISCERNIR RECURRENCIAS Y TENDENCIAS. - El ciclo anual del plancton se estudió a lo largo de 14 años, desde 1984 a 2000, en una estación costera del golfo de Nápoles, con el objetivo de discernir pautas estacionales y tendencias interanuales. La biomasa fitoplanctónica empezaba a aumentar en la columna de agua en febrero-primeros de marzo, y generalmente alcanzaba valores máximos en las capas superiores a finales de primavera. Se solía registrar otro máximo en otoño. Las diatomeas y los fitoflagelados dominaron durante la mayor parte del año. Los ciliados presentaron sus máximos principales en fase con el fitoplancton y estuvieron representados principalmente por pequeños $(<30 \mu \mathrm{m})$ coreotricos desnudos. El mesozooplancton aumentó en marzo-abril, llegando a concentraciones máximas en verano. Los copépodos fueron siempre el grupo más abundante, seguidos de los cladóceros en verano. A la escala interanual, la biomasa autotrófica registró una elevada variabilidad y una tendencia decreciente a lo largo del período de muestreo. La biomasa del mesozooplancton mostró una variabilidad interanual menos marcada. Desde 1995 en adelante, las poblaciones de fitoplancton aumentaron en número de células, pero el tamaño celular se redujo, y en años recientes se han observado floraciones intensas de diatomeas pequeñas y de especies cocoides no determinadas. A pesar de estas variaciones interanuales, las distintas fases del ciclo anual y la presencia de varias especies planctónicas fueron notablemente regulares.

Palabras clave: mar Mediterráneo, fitoplancton, ciliados, mesozooplancton, ciclo estacional, series temporales.

*Received November 2, 2001. Accepted November 19, 2002. 
Es fácil ironizar sobre la pretensión de dar por bien conocido el plancton de una localidad después del estudio de un ciclo anual. Es preciso continuar el estudio por muchos años o indefinidamente con el objectivo de encontrar regularidades de tipo superior... dentro de las cuales se puedan situar las variaciones interanuales.

Margalef (1969).

\section{INTRODUCTION}

Current views about the functioning of marine pelagic ecosystems are based on the conceptualization and generalization of patterns observed in different areas (Sverdrup, 1953; Mann and Lazier, 1996; Longhurst, 1998 and references therein). The existing paradigm for temperate latitudes is a bimodal distribution of autotrophic biomass, with a spring bloom at the start of thermal stratification of the water column and a second bloom during early fall, when the inversion of the buoyancy flux causes the deepening of the seasonal thermocline (Longhurst, 1998; Cebrián and Valiela, 1999). Zooplankton peaks driven by food availability would follow and control phytoplankton biomass. This broad simplification is contradicted by several cases of inconsistencies. As an example, in the Mediterranean Sea a bloom in winter, prior to the thermal stratification, is a quite widespread event (Travers, 1974; Estrada et al., 1985; Duarte et al., 1999). Especially in coastal and shelf waters, plankton abundance and species composition are characterised by a very high degree of spatial and temporal variability. This reflects the variety of terrestrial and offshore as well as atmospheric forcing and internal biological processes to which these boundary areas are subject. The overall complexity also explains why, despite the establishment of a small set of paradigms, no simple and wide-ranging rules have been agreed upon for the annual cycle of plankton and for the functioning of the pelagic ecosystem in coastal waters.

A major limitation in depicting annual cycles is the remarkable interannual variability in environmental factors and plankton responses. In addition, inadequate spatial and temporal scales of sampling may fail to record all the phases of an annual cycle, or overestimate the importance of exceptional events or miss them altogether. Multiannual series of data represent a powerful tool for the reliable reconstruction of plankton seasonal cycles and of their driving factors (Conover et al., 1995; Le Fevre-Lehoerff et al., 1995; Sournia and Birrien, 1995; Southward, 1995; Buecher et al., 1997; Mozetić et al., 1998; Licandro and Ibanez, 2000). In fact, observations repeated over several years allow one to distinguish regular and recurrent patterns from occasional and exceptional events (Goy et al., 1989; Ménard et al., 1994, 1997; Shiganova, 1998). The regularity of the different seasonal stages also represents a key to the understanding of underlying mechanisms, which in turn permits discrimination between local variability from basin-wide signals. In addition, in the long run pluriannual data-sets permit one to trace trends in physical, chemical and biological changes driven by both anthropogenic influence and large scale climatic fluctuations, and constitute the basis for prediction of plankton communities shifts in different hydrographic scenarios (Colijn, 1998 and references therein).

In this paper, temporal variations of plankton biomass and abundance are analysed together with the underlying abiotic dynamics at a fixed site in a coastal area of the Gulf of Naples (Tyrrhenian Sea, Mediterranean), which has been monitored for 14 years in the period 1984-2000. The main aim is to depict general patterns in the seasonal evolution of phyto- and zooplankton populations by highlighting recurrent features in the annual cycle. A preliminary picture of the interannual variability is also provided, in the attempt to identify the first signals of significant oscillations or shifts in the functioning of the pelagic system.

\section{STUDY AREA}

The Gulf of Naples (Fig. 1) is a SW oriented coastal embayment with an average depth of $170 \mathrm{~m}$ over an area of approximately $870 \mathrm{~km}^{2}$ (5.8 surface/volume ratio). As a Mediterranean site, the region receives $20 \%$ more solar irradiance than the flux at a similar latitude in the neighbouring Atlantic Ocean (Bishop and Rossow, 1991). The littoral area is heavily influenced by the land runoff from a very densely populated region. However, due to the general physiography and bottom topography, the inner shelf area is strongly coupled with the offshore waters of the Tyrrhenian Sea. These features result in the coexistence of two subsystems within the Gulf: a eutrophic coastal zone and an oligotrophic area similar to the offshore Tyrrhenian waters (Carrada et al., 1980). The location and width of the boundary between the two subsystems are variable over the seasons (Carrada et al., 1981; Marino et al., 


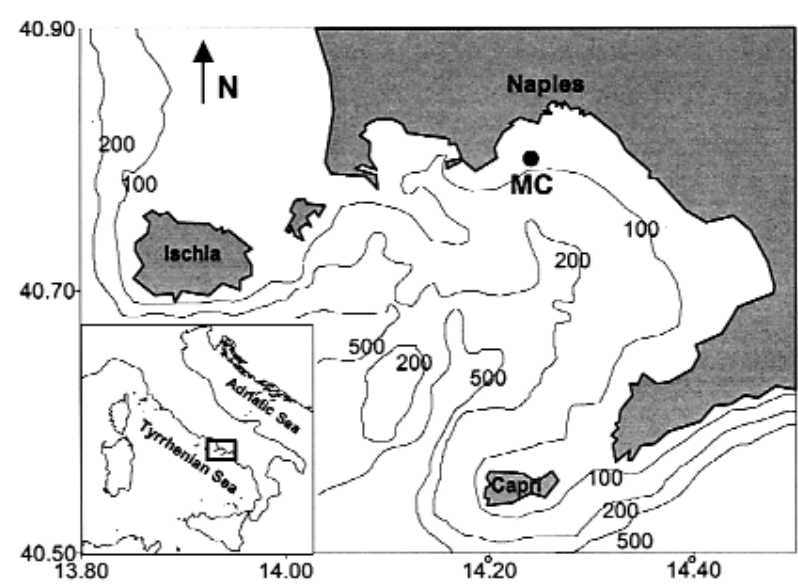

FIG. 1 - Sampling site (st. MC) in the Gulf of Naples (Western Mediterranean Sea).

1984) and highly dynamic water mass distributions may enhance the exchange between the two subsystems (Casotti et al., 2000). A high temporal and spatial variability for physical and chemical parameters characterises the inner part of the Gulf off the city of Naples (Ribera d'Alcalà et al., 1989). Phytoplankton is dominated by diatoms and phytoflagellates for most of the year (Scotto di Carlo et al., 1985), including summer, when surface blooms of small species succeed and overlap each other (Zingone et al., 1990). Zooplankton assemblages in summer show less variable patterns in both space and time (Ianora et al., 1985). As compared to larger cells, picoplankton contributes a minor and more stable fraction of the total biomass and production (Modigh et al., 1996). Sediment trap sampling has revealed high production rates for dinoflagellate cysts from spring to late autumn (Montresor et al., 1998). The autumn bloom in October-November has been associated with calm and stable weather conditions, known as 'St. Martin's Summer' or 'Indian Summer', which frequently are recorded in that period of the year (Zingone et al., 1995). Recurrent patterns in the occurrence of several phytoplankton (Zingone and Sarno, 2001), ciliate (Modigh, 2001) and zooplankton (Mazzocchi and Ribera d'Alcalà, 1995) species have been previously described.

\section{METHODS}

The sampling site (st. $\mathrm{MC}, 40^{\circ} 48.5^{\prime} \mathrm{N}, 14^{\circ} 15^{\prime} \mathrm{E}$ ) is located in the Gulf of Naples (Tyrrhenian Sea) two nautical miles from the coastline, in proximity of the $80 \mathrm{~m}$ isobath (Fig. 1). Sampling is ongoing since January 1984, with one major interruption from
August 1991 through February 1995. The frequency was fortnightly until 1991 and weekly from 1995 to date. Here we present data for the period January 1984-December 2000, resulting from a total number of 440 sampling dates. During the 1984-1991 period, and in a few occasions during the following 1995-2000 period, the hydrocast was performed using 51 Niskin bottles equipped with reversing thermometers. From 1995, CTD and fluorescence profiles were obtained with a SBE911 mounted on a Rosette sampler equipped with Niskin bottles (12 1). For the entire period, sampling depths were $0.5,2$, $5,10,20,30,40,50,60,70 \mathrm{~m}$ for the analysis of the following parameters: salinity, oxygen, nutrients $\left(\mathrm{NO}_{2}, \mathrm{NO}_{3}, \mathrm{NH}_{4}, \mathrm{PO}_{4}, \mathrm{SiO}_{4}\right)$. Total chlorophyll $a$ (chl a) concentrations were determined at selected depths $(0.5,2,5,10,20,40$ and $60 \mathrm{~m})$. Phytoplankton samples were taken from the $0.5 \mathrm{~m}$ bottle and, for the first two years, at selected additional depths. Nutrient concentrations were analyzed according to Hansen and Grasshoff (1983) with a TECHNICON II autoanalyzer. Chlorophyll $a$ concentrations were determined with a spectrophotometer (Strickland and Parsons, 1972) till 1991, and with a spectrofluorometer (Holm-Hansen et al., 1965; Neveux and Panouse, 1987) from 1995 onwards. Phytoplankton samples were fixed with neutralised formaldehyde (0.8-1.6 \% final concentration). Cell counts were performed using an inverted microscope after sedimentation of variable volumes of seawater (1-100 $\mathrm{ml}$ ), depending on cell concentration (Utermöhl, 1958), on two transects representing ca. 1/30 of the whole bottom area of the sedimentation chamber at 400X magnification. For selected species, the identification was checked with an electron microscope. Cells smaller than $2 \mu \mathrm{m}$ generally escaped detection, unless very abundant. For carbon content evaluation, linear measurements were taken on phytoplankton cells routinely over one year of sampling and then, occasionally, on selected samples for species that were rare or variable in size. Carbon content was calculated from mean cell biovolumes using the formula introduced by Strathmann (1967). Ciliates were collected from the $0.5 \mathrm{~m}$ Niskin bottles, in 1984 and from September 1996 onwards, with a interruption in the first half of 2000. Although formol causes loss of naked ciliates as compared to Lugol's solution, borate formaldehyde (1.6\% final concentration) was chosen as fixative as it permits the distinction of chloroplasts within the mixotrophic species. Cells from subsamples of variable volume $(25-250 \mathrm{ml})$ were counted over the whole bot- 
tom of the sedimentation chamber scanned at $340 \mathrm{X}$ magnification with an inverted microscope. For biomass calculations, linear dimensions of the ciliate cells were measured in all samples and biovolumes calculated referring to simple geometrical shapes. Ciliate carbon content was calculated using the con-

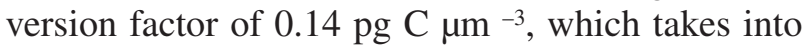
account cell shrinkage caused by formol fixation (Putt and Stoecker, 1989). Mesozooplankton samples were collected with two successive vertical hauls from $50 \mathrm{~m}$ depth to the surface, using a Nansen net (113 cm mouth diameter, $200 \mu \mathrm{m}$ mesh size). One fresh sample was utilised for biomass measurements as dry weight ( $\left.\mathrm{mg} \mathrm{m}^{-3}\right)$ according to Lovegrove (1966). The second sample was immediately preserved with formaldehyde (1.6\% final concentration) for specimen identification and counts which were performed with a dissecting microscope. Details for mesozooplankton count methods are reported in Mazzocchi and Ribera d'Alcalà (1995). Here we present mesozooplankton biomass data for the years 1984-2000, and abundance data only for the period 1984-1990, 1997 and 1998, the rest of samples being currently under taxonomic investigation.

\section{RESULTS}

\section{Seasonal patterns}

\section{Abiotic context}

The temperature variations in the surface layer of the water column (0-10 m; Fig. 2a) followed a sinusoidal pattern, with minimum and maximum monthly averages in March and August, respectively. The lowest annual values were recorded in March (14 \pm $\left.1^{\circ} \mathrm{C}\right)$ and the highest $\left(26 \pm 1.5^{\circ} \mathrm{C}\right)$ in August. Salinity values for the same layer (Fig. 2b) showed frequent spikes of lower and more rarely higher values, superimposed to a sinusoidal pattern which is similar to that observed at other Mediterranean sites (Dyfamed dataset, available at http://www.obsvlfr.fr/jgofs2/sodyf/home.htm) and temperate regions. Salinity maxima $(37.9 \pm 0.2 \mathrm{psu})$ were generally recorded in late September-October and minima $(37.4 \pm 0.2 \mathrm{psu})$ in May. Lateral advection of fresher water from the coast frequently determined a decrease in surface salinity resulting in a sharp halocline. The frequency of these events, obtained by singling out all the cases of surface salinity values
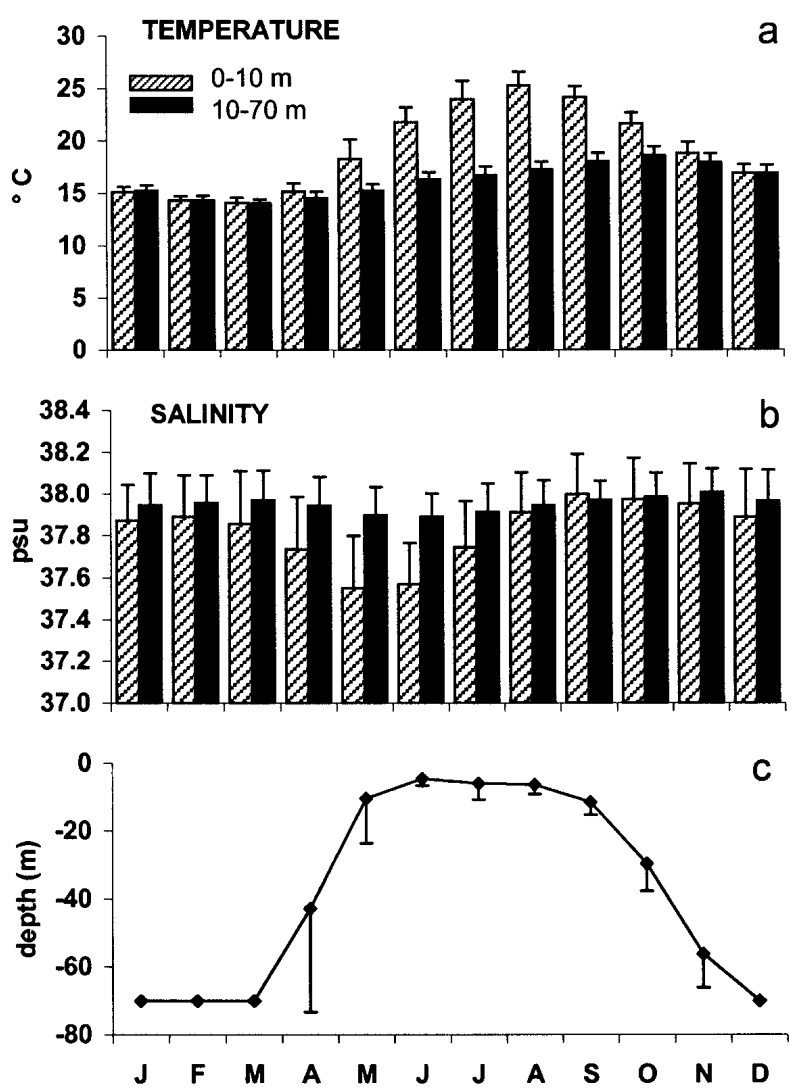

FIG. 2 - Mean seasonal cycle of: a) temperature; b), salinity, and c) depth of the mixed layer at st. MC. Monthly averages and standard deviations for the period 1984-2000.

0.2 psu lower than those recorded at $10 \mathrm{~m}$ on the same dates, was estimated to be $20 \%$ of all sampling dates. Excluding those events, the annual cycle of the stratification due to the seasonal cycle of cooling and warming can be represented as the depth of the mixed layer, here defined as the thickness of the layer within which the density anomaly range was $\leq$ $0.05 \mathrm{~kg} \mathrm{~m}^{-3}$. Seasonal stratification started in April and was completely disrupted from December onwards (Fig. 2c). However, as a consequence of the above-mentioned impact of terrestrial runoff, a pronounced pycnocline was frequently recorded also in winter in an otherwise homogeneous water column. In stratified conditions, low salinity waters floated at the surface thereby enhancing the water column stability and reducing the mixed layer depth. A more detailed view of the described dynamics is shown in the annual cycle of temperature (Fig. 3a, b) and salinity (Fig. 3c, d) for 1986 and 1997. The intermittent runoff events are clearly detectable, e.g. throughout spring and early summer 1986. At seasonal scale, the annual cycle of temperature drives the time course of water column stratification. 

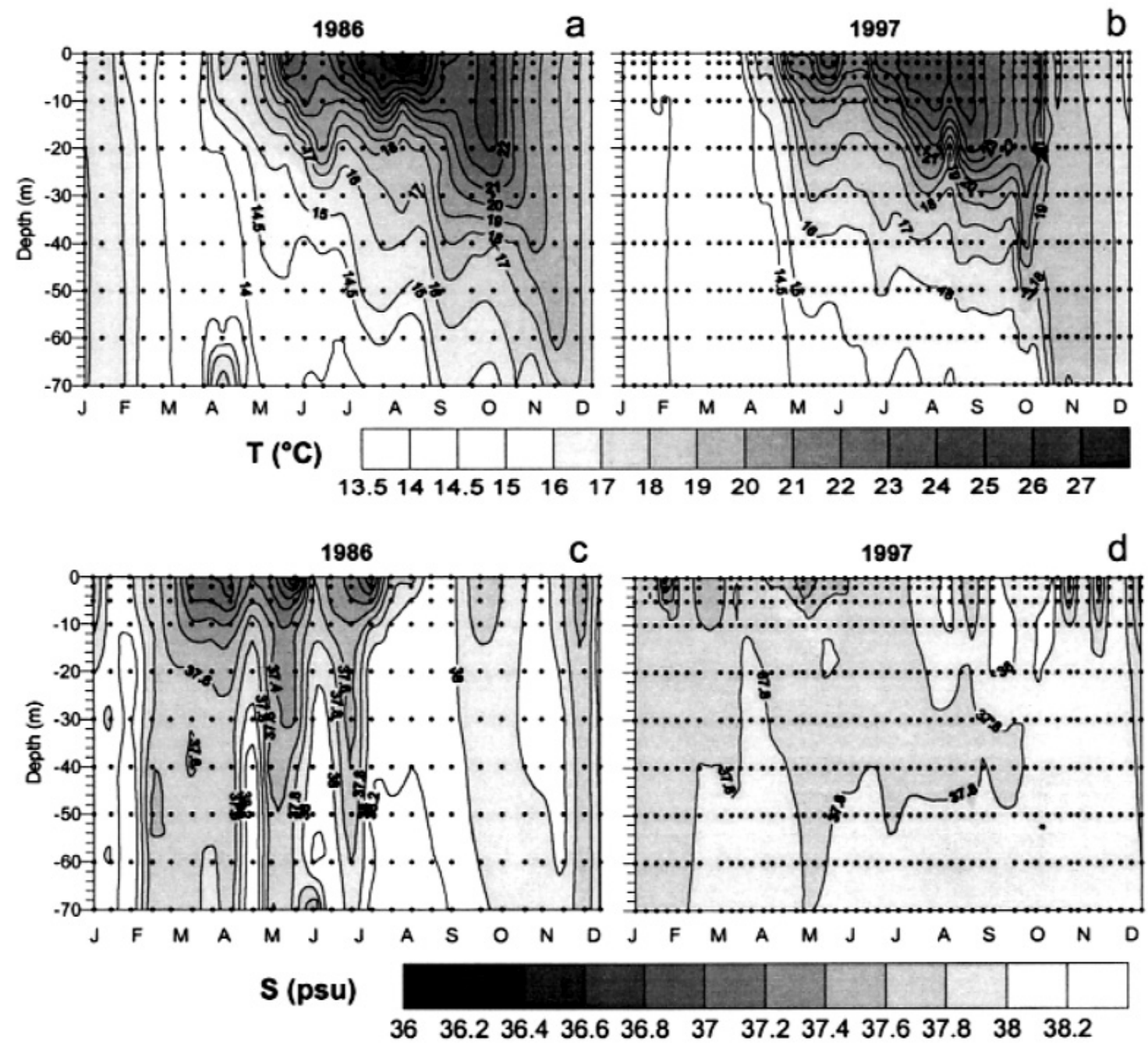

FIG. 3 - Vertical distribution of temperature in 1986 (a) and 1997 (b), and of salinity in 1986 (c) and 1997 (d) at st. MC.

With the exception of summer, dissolved total inorganic nitrogen (TIN) and silica concentrations were generally higher and more variable in the $0-10$ $m$ layers than in the 10-70 m layers (Fig. 4 a, b), in relation with their terrestrial origin. The lowest values for these nutrients were observed in spring-summer whereas phosphate concentrations did not show a clear seasonal trend (Fig. 4c). Interannual variability was very high for all nutrients. It is worth noting that the water column was very seldom nutrient depleted, nutrient concentrations being below the detection limit in only 3-7\% of samples (according to the different nutrients). This fraction decreased to $1-3 \%$ when the depth-integrated values were considered. To obtain a rough estimate of how frequently nutrient concentrations may have controlled phytoplankton stocks, we determined the number of samplings in which each nutrient was below an arbitrary threshold chosen within the range of half-saturation constants reported in the literature (e.g., Romeo and Fisher, 1982; Goldman et al., 2000; Ragueneau et al., 2000; Table 1). Only nitrates were frequently

TABLE 1 - Half-saturation constants $\left(\mathrm{K}_{\mathrm{s}}\right)$ for phytoplankton uptake chosen for each nutrient, and percentage of sampling dates when depth integrated (0-10 and 10-70 m) concentrations of nutrients were lower than $\mathrm{K}_{\mathrm{s}}$.

\begin{tabular}{|c|c|c|c|c|c|c|}
\hline & $\mathrm{NO}_{3}$ & $\mathrm{NO}_{2}$ & $\mathrm{NH}_{4}$ & $\mathrm{PO}_{4}$ & $\mathrm{SiO}_{4}$ & TIN \\
\hline $\mathrm{K}_{\mathrm{s}}\left(\mu \mathrm{mol} \mathrm{l^{-1 }}\right)$ & 0.5 & 0.03 & 0.3 & 0.03 & 0.5 & 0.3 \\
\hline Samplings (\%) with conc. $\leq \mathrm{K}_{\mathrm{s}}(0-10 \mathrm{~m})$ & 43.2 & 20.2 & 18.9 & 13.7 & 14.5 & 8.8 \\
\hline Samplings (\%) with conc. $\leq \mathrm{K}_{\mathrm{s}}(10-70 \mathrm{~m})$ & 48.1 & 8.5 & 22.0 & 18.3 & 9.8 & 2.3 \\
\hline
\end{tabular}



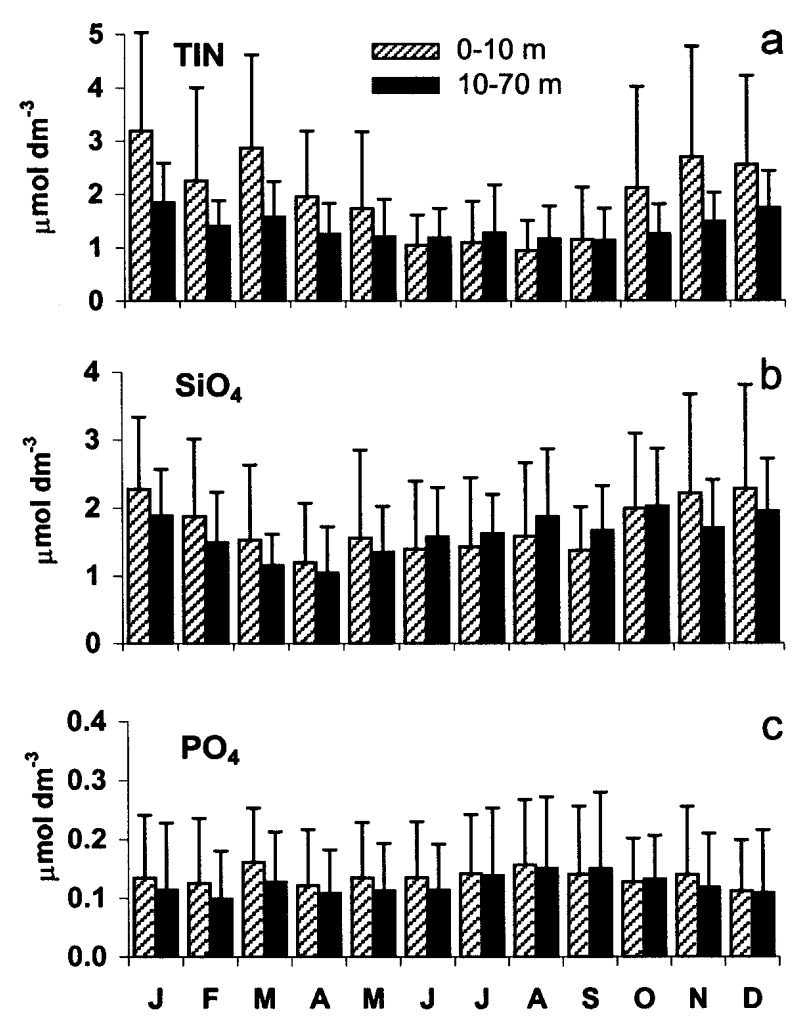

FIG. 4 - Mean seasonal cycle of nutrients at st. MC in the $0-10 \mathrm{~m}$ and 10-70 m layers: a) total inorganic nitrogen (TIN), b) silicates, c) phosphates. Monthly averages and standard deviations for the period 1984-2000.

below the threshold. The fraction of samplings when TIN was below the assigned threshold was $\sim 9 \%$ in the upper layer and $\sim 2 \%$ in the 10-70 m layer. In general, nitrogen appeared to be more frequently close to the threshold than silicon and phosphate. In conclusion, in late spring-summer nutrients were occasionally below the saturation values, but they were rarely exhausted.

\section{Autotrophic biomass and species composition}

Average surface chl $a$ concentrations (Fig. 5a) showed a slight increase in winter, followed by an annual peak in late spring-summer and by a new increase in autumn. The peaks observed in late spring and summer were confined to surface layers and were related to the low salinity waters of terrestrial origin overlying the more salty and dense water column (Fig. 3c, d). In winter and in autumn the increase in biomass occurred over a deeper mixed layer (down to the bottom and to $\sim 40 \mathrm{~m}$, respectively). As a result of the different vertical extension of the blooms, the annual pattern of integrated chl $a$ values (Fig. 5b) differed from what was
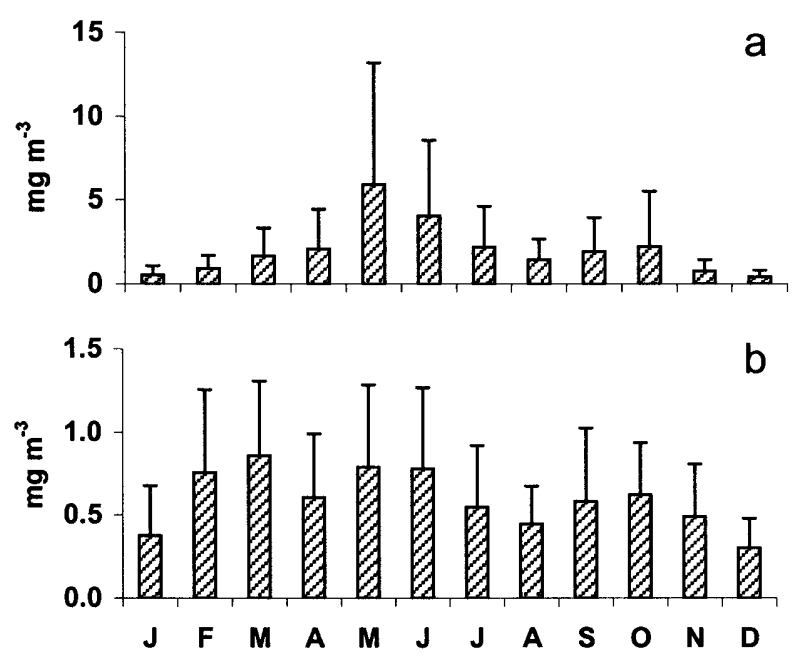

FIG. 5 - Mean seasonal cycle of chlorophyll $a$ at st. MC: a) surface $(0.5 \mathrm{~m})$ concentrations, b) integrated values $(0-60 \mathrm{~m})$. Monthly averages and standard deviations for the period 1984-2000.
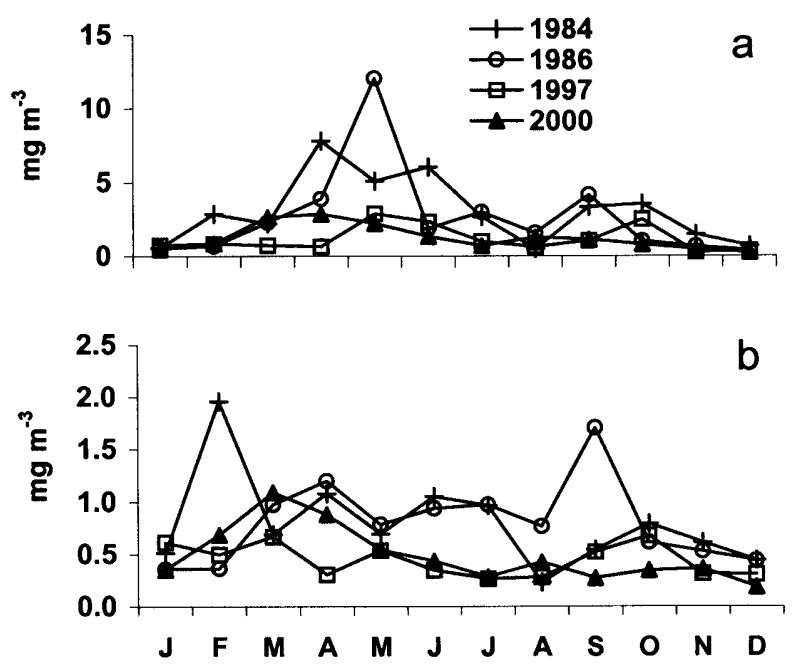

FIG. 6 - Seasonal cycles of chlorophyll $a$ (monthly averages) at st. MC in the years $1984,1986,1997,2000$. a) Surface $(0.5 \mathrm{~m})$ concentrations, b) integrated values $(0-60 \mathrm{~m})$.

observed in surface waters, showing reduced differences among the three annual peaks and between high and low phases. Over the 14 years analysed, the general pattern depicted above for $\operatorname{chl} a$ showed recurrent features. However, a high interannual variability was evident in the timing and extent of peaks and minima, which mainly applies to the summer period but also to the winter and autumn increases (Fig. 6a, b). In addition, in several years one or two of the phases of phytoplankton increase were not detected at all.

Phytoplankton abundance in surface waters followed a pattern similar to $\operatorname{chl} a$, but with no appar- 
ent peak in October (Fig. 7a). Diatoms and small (average $3.6 \mu \mathrm{m}$ ) phytoflagellates were by far the dominant groups throughout the year. As compared to cell numbers, the carbon content revealed a greater relative importance of dinoflagellates and a smaller contribution of phytoflagellates to total biomass (Fig. 7b). The winter-early spring bloom populations were dominated by large colonial diatoms including several Chaetoceros species (e.g. C. compressus, C. didymus), Pseudo-nitzschia delicatissi$m a$ and Thalassionema bacillaris, and by phytoflagellates. From the onset of the stratification throughout the summer, the above-mentioned diatom species were substituted by small-sized ones, often in a non-colonial stage (Skeletonema pseudocostatum, Chaetoceros tenuissimus, $C$. socialis). Intense phytoflagellate blooms, and an increase in dinoflagellate abundances (unarmoured species $<15 \mu \mathrm{m}$, Heterocapsa niei, Prorocentrum triestinum) were also recorded in this period of the year. The coccolithophorid Emiliania huxleyi occasionally contributed to summer blooms. In autumn, several spring and summer diatoms showed a second peak (Thalassiosira rotula, Pseudo-nitzschia delicatissima, Cylindrotheca closterium), whereas other species (Skeletonema menzelii, Dactyliosolen phuketensis, Pseudo-nitzschia multistriata, Leptocylindrus minimus) were generally recorded only in this season. Coccolithophorids (Emiliania huxleyi, Calciopappus caudatus) were also relatively more abundant in autumn.

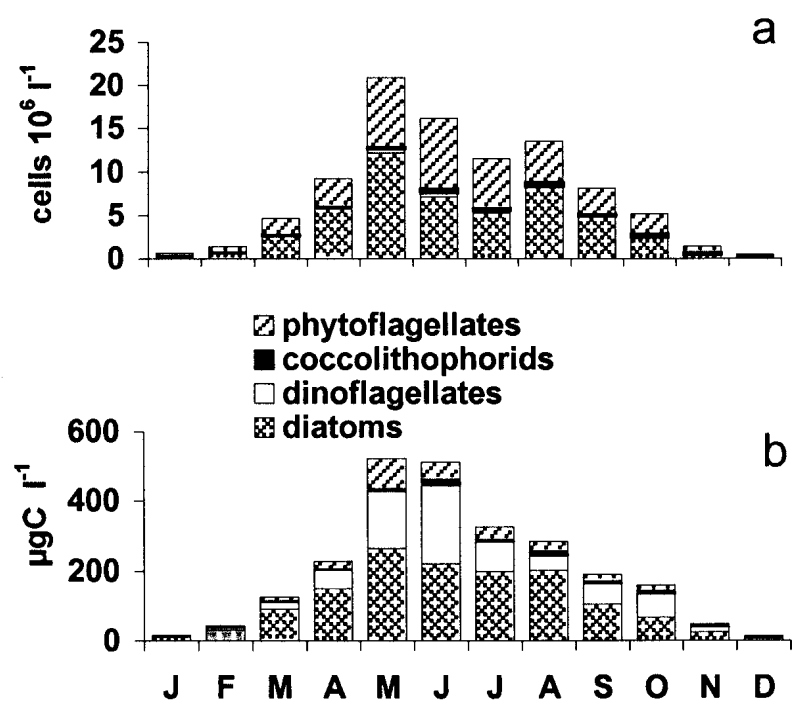

FIG. 7 - Mean seasonal cycle of phytoplankton at st. MC for the period 1984-2000. Monthly average contribution of different taxonomic groups to: a) total abundance, and b) total carbon content.

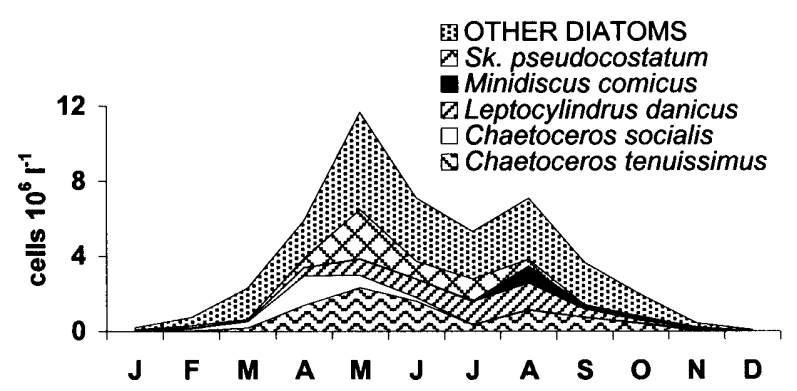

FIG. 8 - Contribution of the five most abundant species to the mean seasonal cycle of total diatom concentrations at st. MC. Monthly averages for the period 1984-2000.

The five most abundant diatom species (Chaetoceros tenuissimus, Skeletonema pseudocostatum, Leptocylindrus danicus, Chaetoceros socialis, Minidiscus comicus) comprised $39.5 \pm 5.8 \%$ of the total diatom population on a mean annual basis (Fig. 8). These species at times constituted the bulk of diatom populations in surface waters, where they succeeded and overlapped each other with a relatively regular pattern. A notable interannual variability was evident in the relative abundance of these species in the phytoplankton assemblage, within which other taxa (e.g. Cylindrotheca closterium and other Chaetoceros and Thalassiosira species) were very abundant periodically or occasionally.

Some species (e.g. the diatom Chaetoceros tenuissimus, the coccolithophorid Emiliania huxleyi) showed a wide distribution over the year,
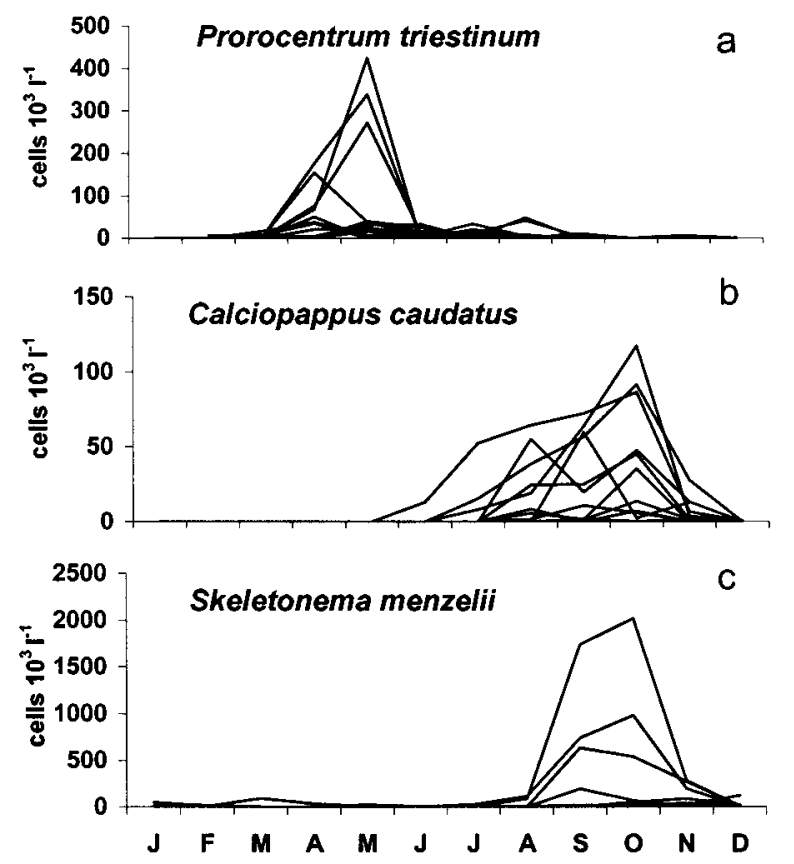

FIG. 9 - Annual cycle (monthly averaged abundances) of: a) Prorocentrum triestinum, b) Calciopappus caudatus, and c) Skeletonema menzelii in 1984-91 and 1995-2000 at st. MC. 
whereas several other species generally occurred in restricted periods (3-8 weeks), with a certain regularity over the years. Among these were the dinoflagellate Prorocentrum triestinum (Fig. 9a), the coccolithophorid Calciopappus caudatus (Fig. 9b), the diatoms Skeletonema menzelii (Fig. 9c), Chaetoceros throndsenii and Pseudo-nitzschia multistriata, and the chrysophyte Dinobryon coalescens.

The vertical distribution, which was analysed in the first two years and in other studies conducted in the area (Zingone et al., 1990, 1995) and confirmed by one-year HPLC profiles (Mangoni, 1999), reflected the seasonal cycle and the frequent decoupling of the upper and lower layers at the site. When the water column was homogeneous, diatoms and flagellates (mainly prymnesiophytes and cryptophytes) alternated as the dominant components along the whole water column. During the stratified season, diatoms were dominant in the upper 5-10 m anytime the thin fresher layer reached the station, otherwise flagellates and unicellular cyanobacteria were spread along the whole water column. In both conditions, species composition in surface waters was generally representative of the most productive population, deep-layer populations being either very similar to surface ones or scarcely abundant and light limited.

\section{Zooplankton biomass and species composition}

Small $(<30 \mu \mathrm{m})$ naked choreotrichs were the most abundant component of the ciliate assemblage at station MC. Sharp fluctuations occurred at a weekly scale, in terms of abundance and biomass, however the interannual variability over the 4 years of observations (1996-2000) was low, the annual average value for biomass ranging between 8.6 and $9.4 \mu \mathrm{g} \mathrm{C}$ $1^{-1}$. In surface waters, total ciliate biomass varied between 0.1 and $99.0 \mu \mathrm{g} \mathrm{Cl}^{-1}$ and abundance between

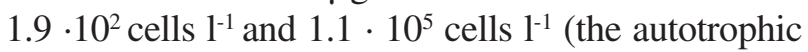
Mesodinium rubrum not included). The highest biomass values were generally recorded in late spring though peaks were observed during the whole period of stratification. Very low values of biomass and abundance were recorded in winter (Fig. 10). Nanociliates $(<18 \mu \mathrm{m}$ Equivalent Spherical Diameter, ESD) contributed, as annual average, $\sim 40 \%$ to ciliate abundance, but $<9 \%$ to biomass (Fig. 10b, c). A major contribution to ciliate biomass was given by larger naked choreotrichs, most of which appeared to be mixotrophic. Tintinnids contribute on average $\sim 10 \%$ to ciliate annual abundance. More than eighty tintin-
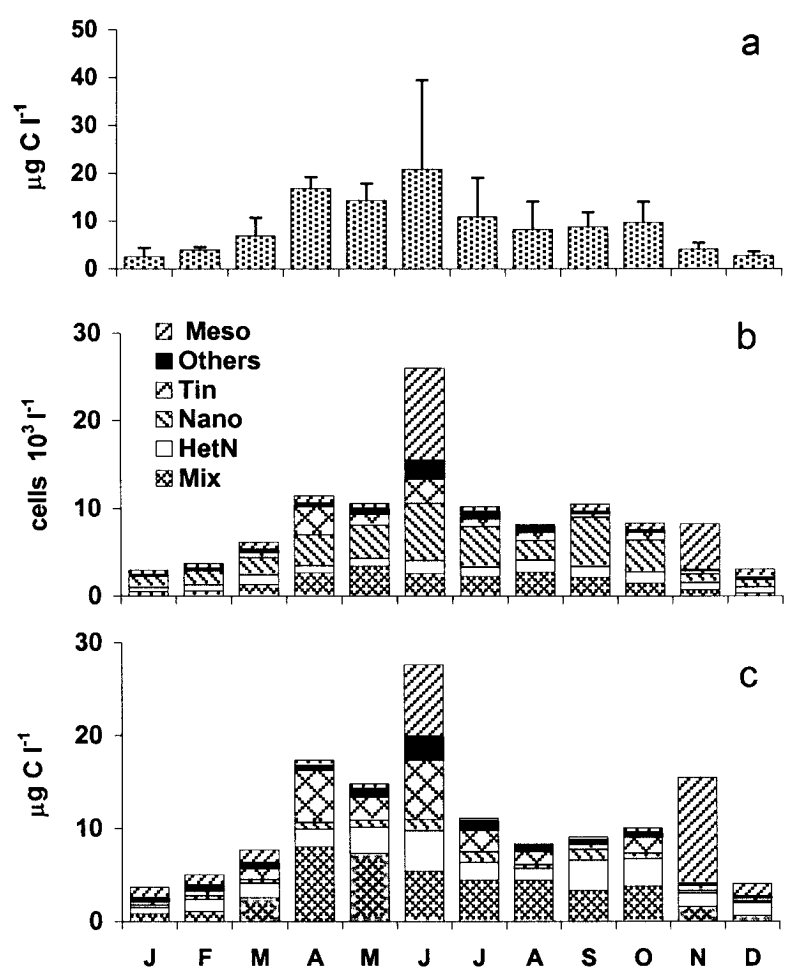

FIG. 10 - Mean seasonal cycle of ciliates at st. MC in the period 1996-2000. Monthly averages for a) total ciliate biomass (Mesodinium rubrum not included), b) contribution of different ciliate guilds to total abundance, and c) contribution of different ciliate guilds to biomass. Mix: mixotrophic; HetN: heterotrophic naked choreotrichs; Nano: nanociliates $<18 \mu \mathrm{m}$; Tin: tintinnids; Others: other ciliates; Meso: Mesodinium rubrum.

nid species have been recorded, but only seven species accounted for $81 \%$ of total tintinnid numbers: Tintinnopsis minuta, T. beroidea, Metacylis annulifera, Eutintinnus tubulosus, Helicostomella subulata, Salpingella curta and S. decurtata (in rank order). These species showed a recurrent seasonal pattern of occurrence, with peaks in different periods of the year. Recurrences could also be distinguished for the naked ciliates as for the three mixotrophic genera Laboea, Strombidium and Tontonia (Modigh, 2001). Laboea strobila reached maximum abundance in early spring, followed by a rich assemblage of several species of Strombidium. Tontonia spp. were abundant from late summer till autumn. The autotrophic Mesodinium rubrum was frequently observed in all seasons and occasionally reached very high abundance (up to $1.6 \cdot 10^{5}$ cells ${ }^{-1}$ ).

For mesozooplankton, a clear seasonal signal could be identified over the years, with the highest values of biomass and abundance generally recorded in mid spring (April-May) and summer (JulySeptember), and the lowest values in winter (December and January; Fig. 11a, b). The annual 

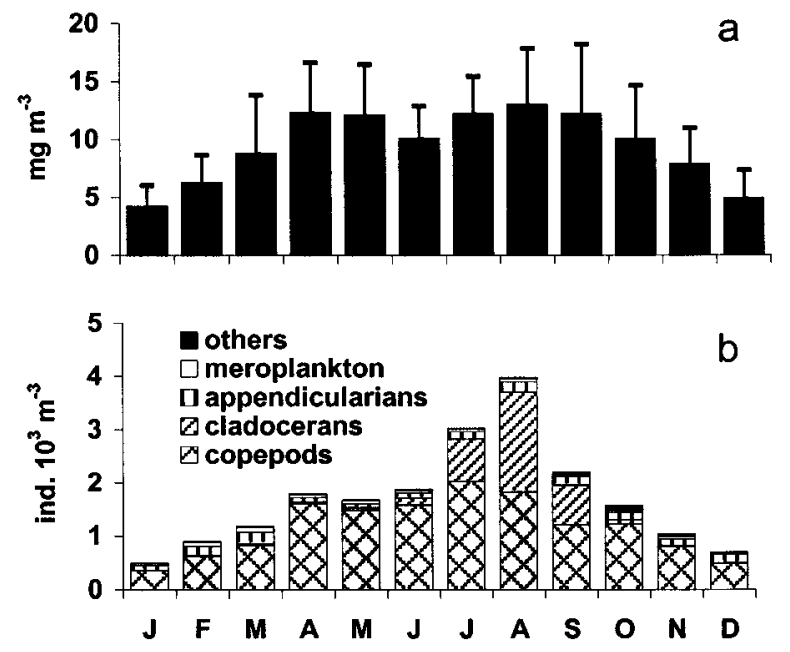

FIG. 11 - Mean seasonal cycle of total mesozooplankton at st. MC: a) monthly averages and standard deviations for biomass as dry weight (1984-2000); b) monthly average contribution of the most abundant taxonomic groups to total abundance (1984-1998).

cycle of biomass was however quite variable over the years in terms of both amplitude and timing of the maxima (Fig. 12). Holoplankton dominated in terms of numerical abundance; in particular copepods were the most abundant group, followed by cladocerans and appendicularians (Fig. 11b). The spring peak was by far dominated by copepods, whereas the summer peak was equally due to copepods and cladocerans. Appendicularians were almost equally distributed throughout the year, but they showed the highest relative contributions from November to March. Meroplankton, mainly represented by larval stages of decapods, gastropods and cirripeds, was more abundant in late winter-early spring, when it contributed up to $10 \%$ of total numbers.

Copepods showed the lowest abundance in late autumn-winter (December-January) and three peri-

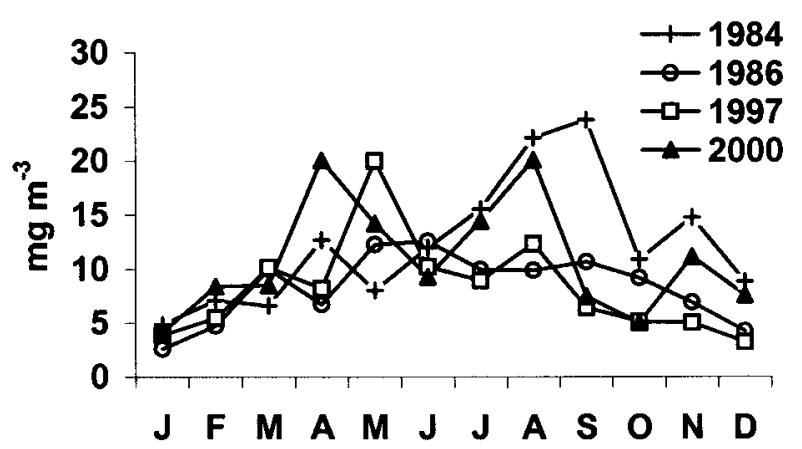

FIG. 12 - Seasonal cycles of mesozooplankton biomass (monthly averages of dry weight) at st. MC in the years 1984, 1986, 1997, 2000.

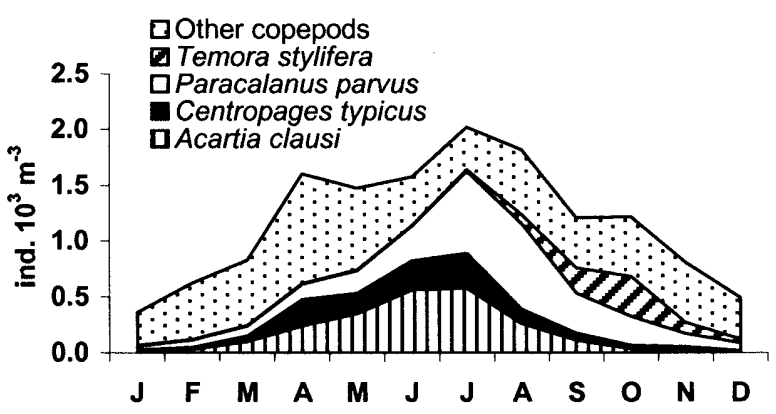

FIG. 13 - Contribution of the four most abundant calanoid species to the mean seasonal cycle of total copepod abundance at st. MC. Monthly averages for the period 1984-1998.

ods of numerical increase: in April, in July-August, when the highest peaks $\left(\sim 2000\right.$ ind. $\left.\mathrm{m}^{-3}\right)$ were generally recorded, and in October (Fig. 11b). During the annual phase of minimum abundance, copepods were represented by numerous species (up to 120). This late autumn-winter assemblage was characterised by the highest relative abundance of small calanoids (Clausocalanus furcatus, C. paululus, Calocalanus spp.), oithonids (Oithona plumifera and Oithona copepodids), and Oncaea spp. Starting from spring, the major feature of the copepod assemblage was the succession of four numerically dominant species (Fig. 13): Acartia clausi and Centropages typicus (peaks in June-July), Paracalanus parvus (July-August), and Temora stylifera (September-October). On a mean annual basis, these species (adults and juveniles) comprised $46 \%( \pm 3.4)$ of total copepod abundance.

The mean annual cycle for many copepod species reflected a very regular seasonality. For example, species such as Oithona similis (Fig. 14a)
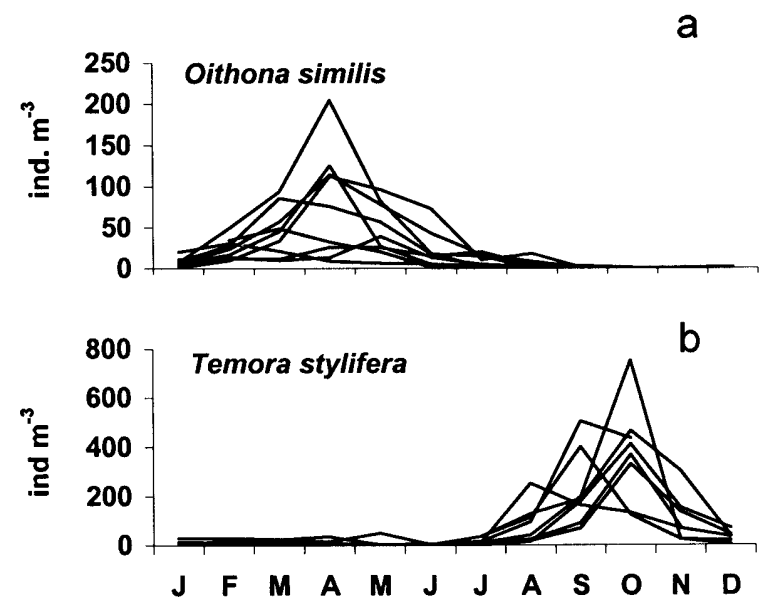

FIG. 14 - Annual cycle (monthly averaged abundances) of the copepods Oithona similis (a) and Temora stylifera (b) at st. MC in 19841990, 1997 and 1998. 


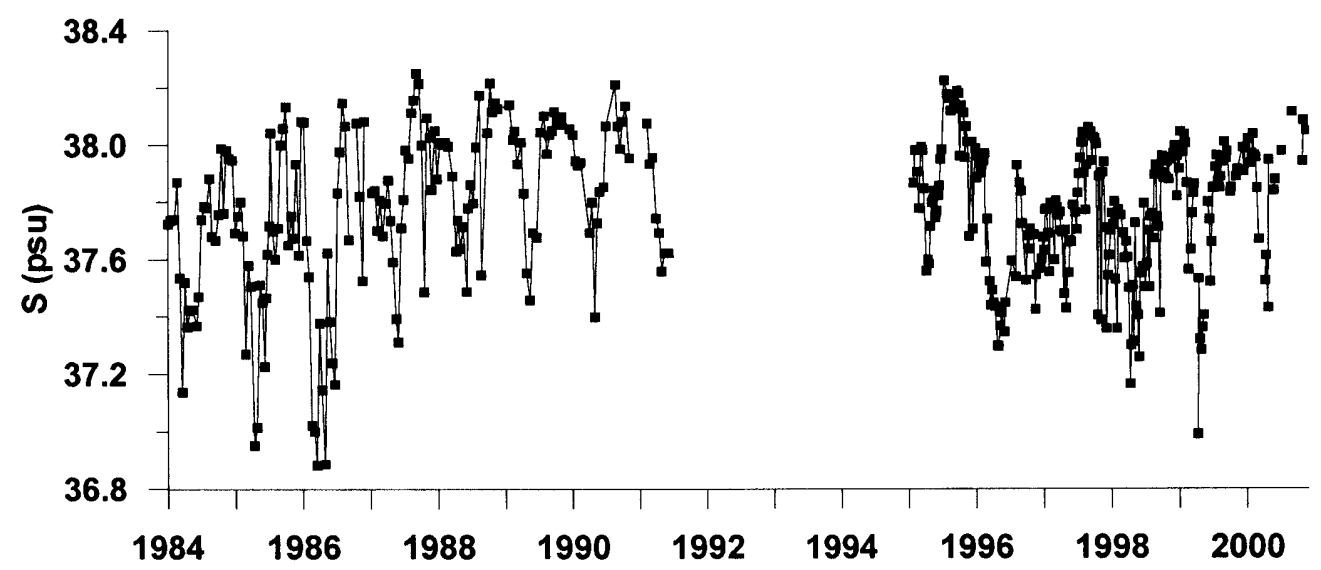

FIG. 15 - Interannual variability of salinity at st. MC for the period 1984-2000. Each value represents the integrated mean in the 0-10 $\mathrm{m}$ layer.

and Temora stylifera (Fig. 14b) showed a repetitive timing of occurrence despite the interannual variability in their abundance.

\section{Interannual variability}

The time series examined is too short to assess long-term (overdecadal) trends, however it was still possible to detect some consistent changes in some of the abiotic and biotic parameters over the years.
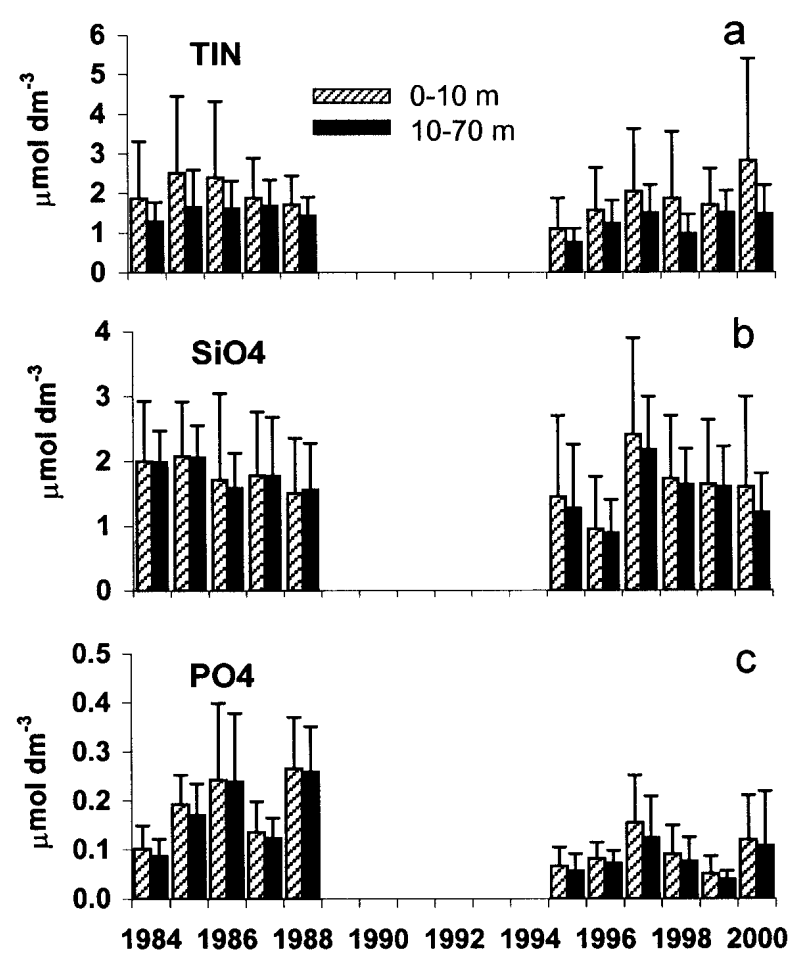

FIG. 16 - Interannual variability of nutrients in the upper $(0-10 \mathrm{~m})$ and lower (10-70 $\mathrm{m}$ ) layers at st. MC. Mean annual values and standard deviations are shown for: a) total inorganic nitrogen (TIN), b) silicates, and c) phosphates.
As expected for a coastal site, the high variability in the hydrographic parameters was reflected in a significant interannual variability. During the first three years of sampling (1984-86) the lowest salinity spikes due to the coastal runoff were recorded (Fig. 15). The salinity increased during the following four years, then it slightly decreased again in 1996-1998.

There was no clear trend in the average values for nutrients (Fig. 16a-c). The variability from one year to the next was very pronounced and it was evident in both the 0-10 and the 10-70 m layers. Lower values in some years of the second part of the series were detected for all nutrients. The decrease in TIN was mostly due to higher frequency of low nitrate concentrations (data not shown). The lack of similarity among the patterns of $\mathrm{Si}, \mathrm{N}$ and $\mathrm{P}$ is also remarkable.

The most striking feature over the observation period was the significant decrease of the autotrophic biomass as revealed by chl $a$ concentrations (Fig. 17). The annual average of integrated $\operatorname{chl} a$ for the whole series was $0.62 \pm 0.15 \mathrm{mg} \mathrm{m}^{-3}$ but the mean annual values notably differed between 1984-1990 $\left(0.45-0.85 \mathrm{mg} \mathrm{m}^{-3}\right.$, median $\left.0.74 \mathrm{mg} \mathrm{m}^{-3}\right)$ and 1996$2000\left(0.42-0.55 \mathrm{mg} \mathrm{m}^{-3}\right.$, median $\left.0.48 \mathrm{mg} \mathrm{m}^{-3}\right)$. The decline was very evident in the surface peaks of late spring-summer, which ranged between 10 and 20 $\mathrm{mg} \mathrm{m}^{-3}$ (up to $36 \mathrm{mg} \mathrm{m}^{-3}$ ) in the first years but rarely exceeded $5 \mathrm{mg} \mathrm{m}^{-3}$ in the last six years. Also the frequency of these blooms related to land inputs diminished in recent years. As for the other annual peaks, the decrease of chl $a$ concentrations was more evident in winter as compared to autumn.

In contrast to the chl $a$ trend, phytoplankton cell numbers showed an increase in the second part of the series which is explained by the greater impor- 


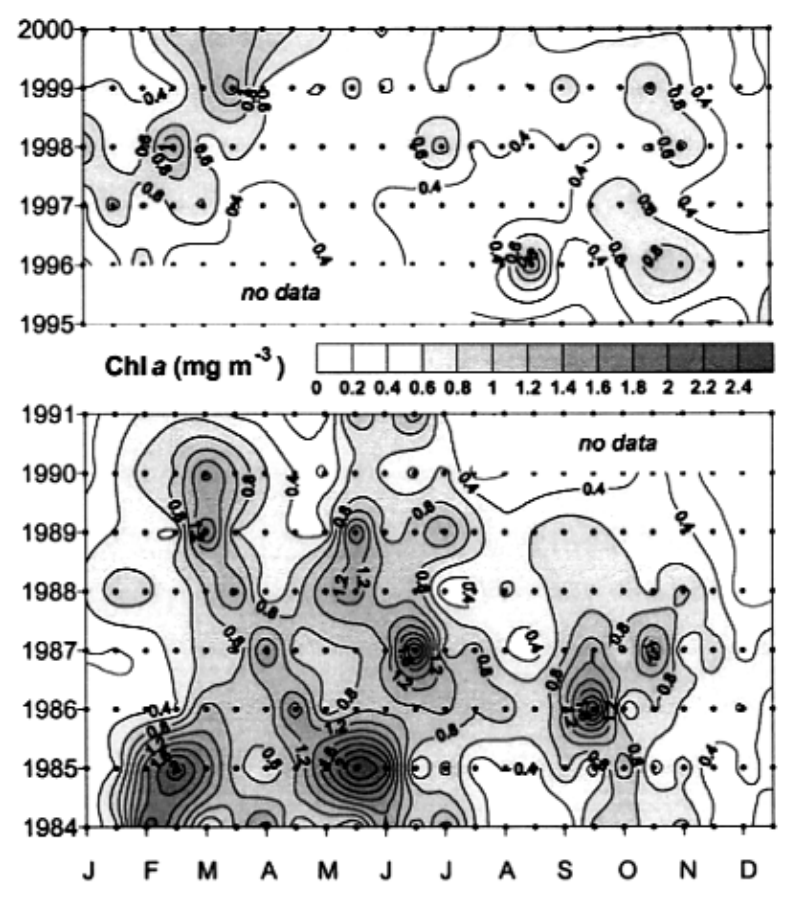

FIG. 17 - Seasonal and interannual variability of chlorophyll $a$ (concentrations integrated over the 0-60 m layer) for the period 19842000 at st. MC.

tance of tiny species, as shown by the decreasing value of the average cell size (ESD; Fig. 18) and by a less marked increase of the carbon content (data not shown). In fact, intense blooms of very small diatoms (e.g. Skeletonema menzelii, Minidiscus comicus, Minutocellus polymorphus), as well as frequent blooms of small coccoids belonging to unidentified algal groups, were more frequently recorded in the last years. Some of these species were not found in the first sampling period, whereas other species, which were commonly found in the first years (e.g. Pseudo-nitzschia subpacifica) have no longer been recorded.

The interannual mean of mesozooplankton biomass was $9.5 \pm 1.7 \mathrm{mg} \mathrm{m}^{-3}$ dry weight (average of 1984-1991 and 1995-2000). The mean annual val-

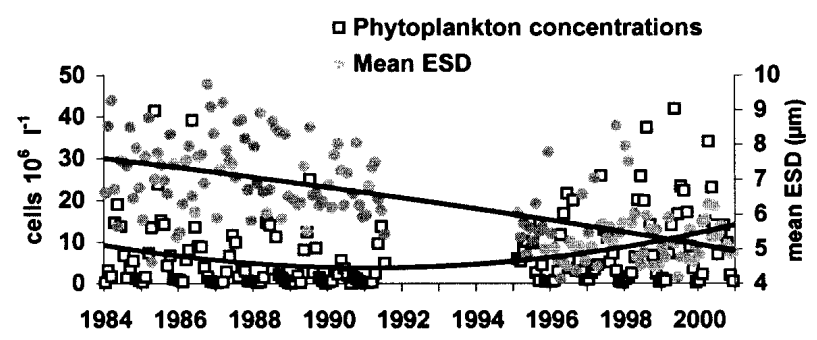

FIG. 18 - Interannual variability of phytoplankton abundance and average cell size (Equivalent Spherical Diameter) at st. MC. Marks represent single samples, and lines represent second-order polynomial fits.
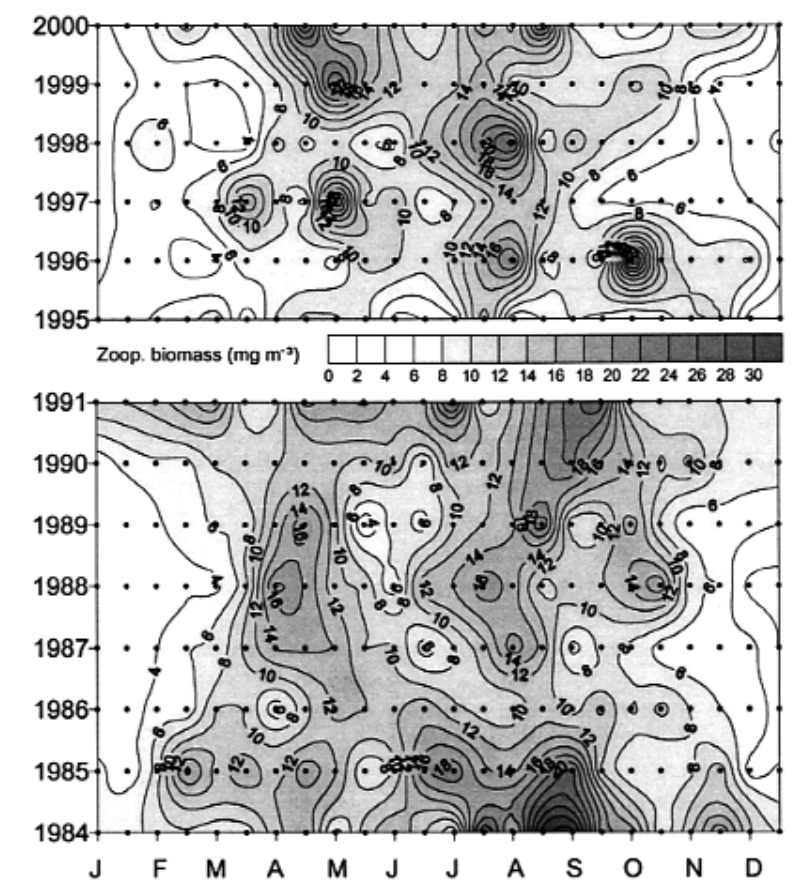

FIG. 19 - Seasonal and interannual variability of mesozooplankton biomass (dry weight) for the period 1984-2000 at st. MC.

ues were slightly higher at the beginning of the series (8.1-12.6 $\mathrm{mg} \mathrm{m}^{-3}$ in 1984-91) than in the following years (7.5-10.8 $\mathrm{mg} \mathrm{m}^{-3}$ in 1995-2000; Fig.19). Overall, the zooplankton biomass showed lower interannual fluctuations as compared to phytoplankton. In the last years, the annual peaks in spring and summer were less separated in time. The long-term analysis of species composition is still in course and we cannot report on possible changes in the community structure yet. However, clear changes can already be outlined in the occurrence of some rare species of the genus Acartia. In the early '90s A. margalefi disappeared, while A. grani and A. longiremis were recorded only since 1998. Other congeners such as A. negligens, which previously occurred only occasionally, showed more regular and representative abundance in the last years.

\section{DISCUSSION}

\section{Seasonal phases}

The seasonal phases of the annual cycle and the parallel development of phyto- and zooplankton communities occur fairly regularly along the multiannual observations at st. MC. The annual cycle of the autotrophic biomass is characterised by a first growth phase in winter, a second one in late spring- 
summer and a third one in autumn. The environmental factors driving the development of these three phases, and the associated biological characteristics, are different.

The first annual bloom generally occurs in February-March prior to the thermal stratification that is assumed to be the prerequisite for the 'classical' spring bloom of the temperate regions (Gran, 1931; Sverdrup, 1953). The biomass increase is recorded over the major part or the whole water column, and it is mainly due to chain-forming diatoms, with a minor contribution of small flagellates. This anticipated bloom is very likely made possible by a limited vertical diffusion, despite an isopycnal water column, in conditions of calm and sunny weather (Sverdrup, 1953; Smetacek and Passow, 1990; Platt et al., 1994; Townsend et al., 1994). In the Mediterranean, a winter phytoplankton bloom appears to be quite widespread, due to recurrent periods of calm weather in the season, generally associated to the expansion of the Siberian high pressure system towards West (Duarte et al., 1999). Indeed, the winter bloom has been defined as the unifying feature for phytoplankton in the Mediterranean Sea (Travers, 1974; Duarte et al., 1999), where it has been recorded all along the coasts (e.g. Margalef and Castellví, 1967; Becacos-Kontos, 1968; Lenzi Grillini and Lazzara, 1978; Dowidar, 1984; Mura et al., 1996; Caroppo et al., 1999; Psarra et al., 2000). Being presumably driven by the above mentioned large-scale meteorological features, it is conceivable that the winter bloom occurs at about the same time at coastal sites over a wider area, although local conditions may detain a precisely synchronised pattern. The same driving mechanism of temporary stabilisation of the isopycnal water column should apply to the offshore waters as well, including the oceanic regions affected by the high pressure system (Townsend et al., 1992). Indeed, studies conducted at deep-sea stations in the eastern Mediterranean Basin (Gotsis-Skretas et al., 1999; Herut et al., 2000) showed annual chlorophyll $a$ peaks in winter. The actual spatial extension and timing of winter blooms in the open Mediterranean sea is not easily assessable with satellite images, since the colour signal in surface waters could be too low for the remote devices to detect.

In winter, the biomass of consumers is generally at the annual minimum for both ciliates and mesozooplankton at st. MC. In this season the smaller size fraction (e.g. copepod nauplii) that we neglected in the present study may notably contribute to zooplankton numbers and/or biomass as reported for other Mediterranean coastal areas (Fernández de Puelles et al., 1998; Calbet et al., 2001). Nevertheless, only a slight amount of the phytoplankton biomass might be efficiently grazed in this period, which would enhance its accumulation in the water column. The most abundant crustacean mesozooplankters occurring in winter (belonging to the copepod genera Clausocalanus, Calocalanus, Oithona and Oncaea) have reduced sizes $(\leq 1 \mathrm{~mm})$, which probably precludes their grazing on the large diatom colonies making up most of the bloom. Moreover, the omnivorous Clausocalanus (Kleppel et al., 1988) show low feeding rates and reduced daily rations (Mazzocchi and Paffenhöfer, 1998), while Oithona and Oncaea are reported to preferentially feed on moving preys (Uchima and Hirano, 1988; Svensen and Kiørboe, 2000) and sinking aggregates (Alldredge, 1972; Lampitt et al., 1993; Ohtsuka et al., 1996), respectively. In addition, the population growth in Oithona, Oncaea and Clausocalanus ( $C$. paululus, $C$. furcatus) is limited by low egg production rates in relation to their egg-carrying strategy (Kiørboe and Sabatini, 1995; Mazzocchi and Paffenhöfer, 1998), and it does not show the abrupt numerical increase typical for late-spring copepods. Appendicularians might significantly contribute to the exploitation of the winter phytoplankton bloom, having high filtration rates (Paffenhöfer, 1973) on a wide size-spectrum of particles, ranging from picoplankton to large diatoms and dinoflagellates (Deibel, 1998 and references therein). Field studies have shown contrasting food selection between appendicularians and copepods (Redden, 1994 cited in Deibel, 1998), which can partially account for what is observed in winter at st. MC, when the two groups show, respectively, the highest and lowest relative abundance in their annual cycle. At this time of the year, a peak in meroplanktonic larvae occurs in the inner Gulf of Naples (Zupo and Mazzocchi, 1998), which testifies for the enhanced reproduction rate of benthic organisms, in agreement with similar findings in other areas (López et al., 1998). It has been argued that several benthic organisms have their reproductive season during this anticipated bloom probably in relation with the availability of phytoplankton sinking from the water column (Townsend and Cammen, 1988; Duarte et al., 1999; Calbet et al., 2001).

In spring (March-April), typical neritic species such as Acartia clausi and Centropages typicus start to increase in abundance. It seems that the few 
adults of these species found in winter benefit of the early phytoplankton bloom in terms of reproductive performances, since both species have their annual peak of egg production rate in February (Ianora, 1998). The numerical growth of juveniles and adults is postponed in the season and speeds up in spring, when they can rely on abundant phytoplankton, mainly represented by colonial diatoms, but also on ciliates, which show a considerable biomass increase from April onwards. Accordingly, both Acartia and Centropages show opportunistic feeding habits (Gaudy and Pagano, 1989; Saiz et al., 1992), being able to switch from herbivory to raptorial feeding on ciliates (Tiselius, 1989; Jonsson and Tiselius, 1990).

Despite the observed seasonal increase of potential predators, phytoplankton at st. MC often show the annual maximum in late spring-summer. The highest biomass values in this season are prevalently due to the lateral transport of fresher waters with their load of nutrients and biomass from the littoral area, though nutrients along the water column are not exhausted after the first annual bloom. The mechanism of nutrient supply allowing for biomass accumulation in this stage of the annual cycle is therefore different from that typical for the spring bloom in temperate areas, which exploits nutrients remineralised and recirculated over the water column during the winter mixing. It is also different from the mechanism invoked for summer blooms in estuarine areas, where high turbidity and instability in spring would cause a delay of the annual peak to more favourable conditions in summer (Cloern et al., 1996; Longhurst, 1998).

The lateral advection of enriched waters allows for biomass buildup throughout the summer. In this season, phytoplankton peaks alternate with periods of low values, reflecting the intermittency of nutrient availability from terrestrial sources as well as the incursions of Tyrrhenian open waters into the inner part of the Gulf (Modigh et al., 1985). In relation to their origin and to the water column structure, late spring and summer blooms are confined to surface layers (Scotto di Carlo et al., 1985) and show a steep gradient from the northeastern part of the Bay of Naples towards southwest and offshore (Ribera d'Alcalà et al. 1989; Zingone et al., 1990). A deep chlorophyll maximum has never been recorded at st. MC, nor, in general, in the inner part of the Gulf. Despite a marked thermal stratification, that should select for flagellate species, diatoms generally dominate phytoplankton populations during the peaks.
Summer diatoms are small-sized and prevalently solitary forms, well adapted to maximise buoyancy (Smayda, 1970; Walsby and Reynolds, 1980). Dinoflagellates show their annual biomass peak in this season and are mainly represented by species $<15 \mu \mathrm{m}$. In deeper layers, a scarce and light-limited flagellate population is generally found, mainly dominated by prymnesiophytes and other undetermined nanoflagellates (Zingone et al., 1990; Mangoni, 1999). Similar assemblages are also found during non-peak phases in summer.

Summer blooms at st. MC are characterized by a relatively well diversified community. In other eutrophic coastal Mediterranean sites, e.g. the northern Adriatic Sea (Gilmartin and Revelante, 1980) summer blooms are also frequent, but show a low species diversity (Margalef and Blasco, 1970; Pucher-Pektović and Marasović, 1980). At st. MC, several diatom species, unidentified nanoflagellates and naked dinoflagellates, alternate or co-occur in this season. The diversity of summer phytoplankton reflects the highly dynamic spatial and temporal conditions in the area (Ribera d'Alcalà et al., 1997). This dynamics would keep the system far from the equilibrium (Huston, 1979; Reynolds, 1993; Reynolds et al., 1993), allowing a quick alternation of different species as well as the overlapping of populations transported to the station from adjacent sites (Zingone et al., 1990).

The summer mesozooplankton community at St. MC is characterized by the outburst of cladocerans, which extend their dominance throughout the Gulf (Ianora et al., 1985). The importance of cladocerans in summer is a common feature for the neritic Mediterranean regions (Della Croce and Bettanin, 1965; Thiriot, 1972-73; Christou et al., 1995; Fonda Umani, 1996; Siokou-Frangou, 1996; Calbet et al., 2001), where these crustaceans rapidly develop because of their parthenogenetic reproduction (Egloff et al., 1997 and references therein). The peaks of Penilia avirostris observed in July-August very often co-occur with peaks of the small suspension-feeding copepod Paracalanus parvus. Due to their remarkable abundance, these two species can have a notable impact on the phytoplankton community, being able to graze on small diatoms, flagellates (Paffenhöfer and Orcutt, 1986; Turner et al., 1988) and heterotrophic dinoflagellates (Suzuki et al., 1999).

In autumn (October-November), the last annual growth phase of plankton is recorded, which is in part due to a second peak of the diatom species also 
present in spring or summer and in part to species typical of the season. The mechanisms underlying the biomass increase in this period are different from those invoked for the classical autumn blooms. These blooms are normally triggered by the enhanced nutrient availability deriving from the erosion of the thermocline, in light conditions still favourable for net growth (e.g. Margalef, 1969). In the case of the Gulf of Naples, and probably in other coastal regions of the central and southern Mediterranean Sea, the erosion of the thermocline cannot cause a significant increase for vertical fluxes of nutrients because the main nutricline is below the depth reached by the autumn mixing (e.g. Carrada et al., 1980). As in summer, nutrients supporting the autumn bloom derive from terrestrial sources, which is reflected in a marked coast-offshore gradient for phytoplankton biomass and primary production (Zingone et al., 1995). Meteorological factors and enhanced circulation, coupled with the deepening of the mixed layer, favour the dispersion of these nutrients, thus allowing phytoplankton growth over larger water masses as compared to summer. Favourable weather conditions known as 'Indian summer' (Kalnicky, 1987) or 'St Martin's summer', are recurrent between October and November and allow for production rates that can equal summer peaks, despite the lower light availability in this season (Zingone et al., 1995). Therefore, similarly to the winter bloom, the autumn bloom is made possible by large scale meteorological factors and could hence be common to other coastal areas.

In contrast with the declining phase for total mesozooplankton biomass, at this time of the year copepods generally show a slight increase, reaching abundances comparable to those recorded in spring. Assemblages are however distinct, the main species being the calanoids Temora stylifera and Clausocalanus furcatus and the cyclopoid Oithona plumifera. T. stylifera regularly shows its annual peak in this season at basin scale in the Western Mediterranean (Dauby, 1980; Gaudy, 1972; Licandro and Ibanez, 2000; Calbet et al., 2001) and in the Adriatic Sea (Cataletto et al., 1995), whereas C. furcatus and $O$. plumifera are reported to dominate in this season also in the open waters of oligotrophic basins such as the Eastern Mediterranean (SiokouFrangou et al., 1997). The above-mentioned copepod species display a very different swimming and feeding behaviour (Paffenhöfer, 1998; Mazzocchi and Paffenhöfer, 1999; Paffenhöfer and Mazzocchi, 2002), which allow them to exploit the large variety of food resources made available by the phytoplankton bloom and the ciliate peak. Therefore, the autotrophic biomass accumulation in this period cannot be explained by a reduced grazing pressure, as hypothesized for other areas (Smayda, 1957; Cushing, 1975).

The seasonal dynamics of the planktonic communities depicted above can hardly be defined a classical succession (Smayda, 1980). In fact, the nature of the sampling site with the observed alternation of distinct water masses of either terrestrial or offshore origin does not allow for the typical development of phytoplankton communities from the pioneer early stages towards a mature phase. Especially in summer, the succession is repeatedly set back to its early stages by nutrient inputs of terrestrial origin. The system is probably prevented from evolving towards the stage dominated by red-tide dinoflagellates (Margalef, 1978, 1997; Reynolds and Smayda, 1998) by the frequent disturbance induced by lateral advection of inshore or offshore waters.

The phases of the seasonal development of phytoplankton populations differ from the classical schemes, yet the same situations tend to re-occur every year around the same dates. Moreover, a recurrence is shown in the seasonal occurrence of several species, independently from their taxonomic position and known life strategies. This regularity is evident despite the notable interannual differences in the bulk environmental and biological characteristics, and highlights the role of biological processes at the species level. The occurrence of a number of species in selected periods of the year appears constant over several decades. In fact, some species recorded in investigations of more than 60 years ago, such as Skeletonema pseudocostatum (as S. costatum) or some colonial Chaetoceros (Issel, 1934; De Angelis, 1956), are still collected around the same periods of the year. This applies to some ciliate species as well. In an area very close to the site of st. MC, Issel (1934) found the dominant tintinnid species to be Tintinnopsis beroidea, which formed dense clouds in early spring, similarly to our findings (Scotto di Carlo et al., 1985; Modigh and Castaldo, 2002). On the other hand, the other dominant species reported by Issel (1934) are at present rare or extremely rare.

Regularities are even more evident for mesozooplankton as compared to phytoplankton and ciliate populations. The dominant copepod species represent a very consistent feature of the communities throughout the years (Scotto di Carlo et al., 1985; 
Mazzocchi and Ribera d'Alcalà, 1995). Moreover, the recurrences observed in the timing of appearance and succession of congener species, including the rare ones (Mazzocchi and Ribera d'Alcalà, 1995) suggest that for most zooplankton the seasonal cycle of populations is basically triggered by the specific life-history traits and, mainly, the numerical amplitude of the population development seems to be tuned with food availability.

\section{Interannual variability}

The main purpose of this paper was to provide an outline of the seasonal cycle based on multiannual observations. At the same time, a first attempt was also made to discern signals against the noise of the interannual variability that could indicate significant trends or oscillations in the dynamics of the pelagic system. The most striking change recorded in our time series is the significant decrease of the autotrophic biomass starting from the third year of sampling. The decline was rather evident in all seasons but particularly from late winter through summer. Zooplankton biomass was also higher in the first years, mainly in relation to higher abundance of Paracalanus parvus populations (Mazzocchi and Ribera d'Alcalà, 1995). The decline in the second period of sampling was less evident as compared to phytoplankton biomass. Long-term variations were also recorded in other environmental and biological parameters but, as examined at this broad scale, a common pattern of variation is hardly detectable. In fact, some consistent features emerge e.g. in the highest phyto- and zooplankton biomass values in the first two years in correspondence with the highest salinity anomalies and nutrient concentrations. However, the relationships among these variables are much less clear in the second period of sampling, which does not allow for a simple explanation to account for the observed changes over the whole period.

Several hypotheses can be put forward on factors possibly driving the observed changes, which will require more extensive analyses, including also the retrieval of meteorological data and information on nutrient inputs from coastal outlets. The low salinity values recorded in the first period of sampling could be the result of anomalous years in term of either terrestrial runoff or circulation patterns in the Gulf, or both. Remediation strategies and regulation on sewage effluent could also be responsible for changes in nutrient supplies, although not all nutri- ents followed the same trend in the last five years.

Significant variations over the sampling period were also recorded for phytoplankton cell numbers. Cell numbers increased in the last years despite the observed chl $a$ decline, but resulted in a lower carbon content due to the increased importance of small-sized cells. The augmented importance of small cells, along with a higher percentage of nanoflagellates and, possibly, of heterotrophic species, suggest that changes may be taking place in the trophic conditions of the system with increment in regenerated production and an increase of the relative importance of the microbial loop.

The long-term patterns of rare copepod species suggest that subtle changes are occurring in the area. Some of the signals that are observed at our fixed station apparently occur at larger basin scale. This seems to be the case for the absence in the last years of Acartia margalefi, that has disappeared also from coastal lakes in the Lazio Region (Tyrrhenian Sea; R. Coen, pers. comm.) and in the Venice Lagoon, where it has been replaced by $A$. tonsa (Comaschi et al., 1999-2000). The changes observed in the planktonic system in the Gulf of Naples could hence represent a symptom of changes occurring at a much wider spatial scale rather than the response to local forcings.

\section{CONCLUDING REMARKS}

The analysis of the multi-annual series of data allowed the reconstruction of a consistent picture of the seasonal cycle of plankton for the area considered, which would not have been possible with information based on just one or a few years. Furthermore it also permitted the detection of its main features. A few of them refine and integrate some of the generalizations based on other data sets.

In particular, our data confirmed that the magnitude of phytoplankton and zooplankton peaks and their timing may vary from year to year but the different phases of the annual cycle are recognizable with a high degree of reliability. At our site, three different growth phases are discernable in the seasonal cycle, and two of them depend on the interplay between large scale forcing and local terrestrial impact. The winter and autumn blooms are very likely related to large-scale meteorological events and hence represent the local expression of basinwide signals, whereas late spring-summer blooms are local phenomena, being driven by lateral advec- 
tion of nutrients and biomass from coastward sites. These results support the relevance of time series of data, even in coastal regions, to detect regularities and trends that reflect large scale processes.

The choice of a single sampling station and of the fortnight-weekly sampling scale reflects the eternal compromise between resources and needs. Nevertheless, the recurrence of seasonal events over the years and their correspondence with the abiotic dynamics are clearly detectable. A remarkable feature is the regularity in the succession within all the compartments of plankton. There are some subtleties involved here. The abundance and timing of occurrence of each species might change from year to year, and some species also apparently disappear in the years. However, the pattern of occurrence of several phyto- and zooplankton species is highly predictable, notwithstanding the marked interannual variability of the abiotic context. Therefore, the different phases of the seasonal cycle are more safely resolved based on species occurrence as compared to bulk properties. It would then be hard to assume that such behaviour is due to a Markovian process. Indeed, organisms display a long lasting biological 'memory'.

Our data suggest that resource availability, as determined by instantaneous values of state variables, may explain only part of the temporal variance of plankton. As an example, the evident decrease in autotrophic biomass over the last years is not easily accounted for by either a consistent decrease in nutrient availability or an increase in grazing pressure by zooplankton. The Gulf of Naples, as typical for coastal sites, has highly variable nutrient concentrations and is seldom nutrientdepleted. In addition, mesozooplankton seems to be poorly affected by the decrease of its food resource. This may suggest that some mechanisms of the carbon transfer in coastal regions are still elusive. On the other hand, changes in physical factors, leading to a change in the water column structure and/or in the residence times of water bodies in the Gulf, might have a significant role in the observed interannual variations.

The regularity in the occurrence of species against the quantitative interannual variability suggests that biological rhythms regulate the temporal dynamics of the communities, whereas the abiotic forcing modulates the amplitude of the growth phases. This stresses the need for studying the biological variability at the organism level, taking into account the functional morphology and the life strategies of the single species. Further analyses are in progress on the same data-set, which is continuously incremented by on-going sampling. Complementary studies, e.g. on remote sensing data and variability at small temporal scales, along with laboratory experiments on life-cycles, ecology and behaviour of individual species, are also underway to improve the understanding of the biological signals we tracked at our study site.

\section{ACKNOWLEDGMENTS}

We wish to thank the crew of R/V Vettoria for their support during the sampling, Ciro and Gianluca Zazo for their helpful collaboration in many phases of the activity in the field and in the laboratory. The Accordo di Programma MURST-CNR 'Ecosistemi Marini' (SINAPSI) has supported this work. This paper is dedicated to the memory of Bruno Scotto di Carlo without whom our activity would have never started, Vincenzo Tramontano without whom it would have never been possible and Patrizia Mascellaro who shared our efforts for too short a time.

\section{REFERENCES}

Alldredge, A.L. - 1972. Abandoned larvacean houses: a unique food source in the pelagic environment. Science, 177: 885-887.

Becacos-Kontos, T. - 1968. The annual cycle of primary production in the Saronikos Gulf (Aegean Sea) for the period November 1963-October 1964. Limnol. Oceanogr., 13: 485-489.

Bishop, J. and W. Rossow. - 1991. Spatial and temporal variability of global surface solar irradiance. J. Geophys. Res., 96: 1683916858.

Buecher, E., J. Goy, B. Planque, M. Etienne and S. Dallot. - 1997. Long-term fluctuations of Liriope tetraphylla in Villefranche Bay between 1966 and 1993 compared to Pelagia noctiluca pullulations. Oceanol. Acta, 20: 145-157.

Calbet, A., E. Garrido, M. Saiz, M. Alcaraz and C.M. Duarte.2001. Annual zooplankton succession in coastal NW Mediterranean waters: the importance of the smaller size fractions. $J$. Plankton Res., 23: 319-331.

Caroppo, C., A. Fiocca, P. Sammarco and G. Magazzù. - 1999 Seasonal variations of nutrients and phytoplankton in the coastal SW Adriatic Sea (1995-1997). Bot. Mar., 42: 389-400.

Carrada, G.C., E. Fresi, D. Marino, M. Modigh and M. Ribera d'Alcalà. -1981 . Structural analysis of winter phytoplankton in the Gulf of Naples. J. Plankton Res., 3: 291-314.

Carrada, G.C., T.S. Hopkins, G. Bonaduce, A. Ianora, D. Marino, M. Modigh, M. Ribera d'Alcalà and B. Scotto di Carlo. - 1980. Variability in the hydrographic and biological features of the Gulf of Naples. P.S.Z.N.I: Mar. Ecol., 1: 105-120.

Casotti, P., C. Brunet, B. Arnone and M. Ribera d'Alcalà. - 2000 Mesoscale features of phytoplankton and planktonic bacteria in a coastal area as induced by external water masses. Mar. Ecol. Prog. Ser., 195: 15-27.

Cataletto, B., E. Feoli, S. Fonda Umani and S. Cheng-Yong. - 1995. Eleven years of time-series analysis on the net-zooplankton community in the Gulf of Trieste. ICES J. Mar. Sci., 52: 669-678.

Cebrián, J. and I. Valiela. - 1999. Seasonal pattern in phytoplankton biomass in coastal ecosystems. J. Plankton Res., 21: 429-444. 
Christou, E.D., I. Siokou-Frangou and E. Papathanassiou. - 1995. Annual cycles of cladocerans in the Saronikos Gulf (Hellas). Rapp. Comm. Int. Mer Médit., 34: 206.

Cloern, J.E. - 1996. Phytoplankton bloom dynamics in coastal ecosystems: a review with some general lessons from sustained investigation of San Francisco Bay, California. Reviews of Geophysics, 34: 127-168.

Colijn, F. - 1998. The temporal variability of plankton and their physico-chemical environment. ICES J. Mar. Sci., 55: 557-561.

Comaschi, A., F. Acri, F. Bianchi, M. Bressan and E. Camatti. 1999-2000. Temporal changes of species belonging to the Acartia genus (Copepoda: Calanoida) in the northern basin of the Venice lagoon. Boll. Museo St. Nat. Venezia, 50: 189-193.

Conover, R.J., S. Wilson, G.C.H. Harding and V.P. Vass. - 1995. Climate, copepods and cod. Some thoughts on the long-range prospects for a sustainable northern cod fishery. Climate Res., 5: 69-82.

Cushing, D.H. - 1975. Marine ecology and fisheries. Cambridge University Press, Cambridge.Dauby, P. - 1980. Cycle annuel du zooplancton de surface de la baie de Calvi (Corse). Biomasse totale et plancton copépodien. Oceanol. Acta, 3: 403-407.

De Angelis, C.M. - 1956. Ciclo annuale del fitoplancton del Golfo di Napoli. Boll. Pisc. Idrobiol., 1: 37-55.

Deibel, D. - 1998. Feeding and metabolism of Appendicularia. In: Q. Bone (ed.), The Biology of Pelagic Tunicates, pp. 139-149. Oxford University Press, New York.

Della Croce, N. and S. Bettanin. - 1965. Osservazioni sul ciclo biologico di Penilia avirostris Dana del Golfo di Napoli. Boll. Mus. Ist. Biol. Univ. Genova, 33: 49-68.

Dowidar, N.M. - 1984. Phytoplankton biomass and primary productivity of the South-Eastern Mediterranean. Deep-Sea Res. 31: 983-1000.

Duarte, C.M., S. Agustí, H. Kennedy and D. Vaqué. - 1999. The Mediterranean climate as a template for Mediterranean marine ecosystems: the example of the northeast Spanish littoral. Prog. Oceanogr., 44: 245-270.

Egloff, D.A., P.W. Fofonoff and T. Onbè. - 1997. Reproductive biology of marine cladocerans. Adv. Mar. Biol., 31: 79-167.

Estrada M., F. Vives and M. Alcaraz. - 1985. Life and the Productivity of the Open Sea. In: R. Margalef (ed.), Western Mediterranean, pp. 148-197. Pergamon Press, Oxford.

Fernández de Puelles, M.L., J. Jansà, A. Morillas, B. Amengual and L. Vicente. - 1998. Spatial and seasonal variability of the zooplankton in the Balearic Sea (Western Mediterranean). Rapp. Comm. Int. Mer Médit., 35: 430-431.

Fonda Umani, S. - 1996. Pelagic production and biomass in the Adriatic Sea. Sci. Mar., 60:65-77.

Gaudy, R - 1972. Contribution à la connaissance du cycle biologique des copépodes du Golfe de Marseille. 2. Étude du cycle biologique de quelques espèces caractéristiques. Tethys, 4: $175-242$.

Gaudy, R. and M. Pagano. - 1989. Nutrition of copepods under conditions of the Mediterranean lagoon as a function concentration of food particles and temperature. Ekologiya Morya, 33: 57-67.

Gilmartin, M. and N. Revelante. - 1980. Nutrient input and the Summer nanoplankton bloom in the northern Adriatic Sea. P.S.Z.N.I: Mar. Ecol., 1: 169-180.

Goldman, J.C., and P.M. Glibert - 1983. Kinetics of inorganic nitrogen uptake by phytoplankton. In: E.J. Carpenter and D.G. Capone (eds.), Nitrogen in the marine environment, pp. 233274. Academic Press, New York.

Gotsis-Skretas, O., K. Pagou, M. Moraitou-Apostolopoulou and L. Ignatiades. - 1999. Seasonal horizontal and vertical variability in primary production and standing stocks of phytoplankton and zooplankton in the Cretan Sea and the Straits of the Cretan Arc (March 1994-January 1995). Prog. Oceanogr., 44: 625-649.

Goy, J., P. Morand and M. Etienne. - 1989. Long-term fluctuations of Pelagia noctiluca (Cnidaria, Scyphomedusa) in the Western Mediterranean Sea. Prediction by climatic variables. Deep-Sea Res., 36: 269-279.

Gran, H.H. - 1931. On the conditions for the production of plankton in the sea. Rapp. P.-v. Réun. Cons. Int. Explor. Mer, 75: 37-46.

Hansen, H.P. and K. Grasshoff. - 1983. Automated chemical analysis. In: K. Grasshoff, M. Ehrhardt and K. Kremlin (eds.), Methods of seawater analysis, pp. 347-379. Chemie, Weinheim.

Herut, B., A. Almogi-Labin, N. Jannink and I. Gertman. - 2000. The seasonal dynamics of nutrient and chlorophyll $a$ concen- trations on the SE Mediterranean shelf slope. Oceanol. Acta, 23: 771-782.

Holm-Hansen, O., C.J. Lorenzen, R.W. Holmes and J.D.H. Strickland. - 1965. Fluorimetric determination of chlorophyll. $J$. Cons. Perm. Int. Explor. Mer, 30: 3-15.

Huston, M. - 1979. A general hypothesis of species diversity. Am. Nat., 113: 81-101.

Ianora, A. - 1998. Copepod life history traits in subtemperate regions. J. Mar. Syst., 15: 337-349.

Ianora, A., M.G. Mazzocchi and B. Scotto di Carlo. - 1985. Zooplankton community structure for coastal waters of the Gulf of Naples, summer of 1983. Rapp. Comm. Int. Mer Médit., 29: 299-300.

Issel, R. - 1934. Ciclo annuale del microplancton di superficie nel Golfo di Napoli (golfo interno). Pubbl. Staz. Zool. Napoli, 14: $1-50$.

Jonsson, P.R. and P. Tiselius. - 1990. Feeding behaviour, prey detection and capture efficiency of the copepod Acartia tonsa feeding on planktonic ciliates. Mar. Ecol. Prog. Ser., 60: 35-44.

Kalnicky, R.A. - 1987. Seasons, singularities, and climatic changes over the mid latitudes of the Northern Hemisphere during 18991969. J. Climate Appl. Meteorol., 26: 1496-1510.

Kiørboe, T. and M. Sabatini. - 1995. Scaling of fecundity, growth and development in marine planktonic copepods. Mar. Ecol. Prog. Ser., 120: 285-298.

Kleppel, G.S., D. Frazel, R.E. Pieper and D.V. Holliday. - 1988 Natural diets of zooplankton off southern California. Mar. Ecol. Prog. Ser., 49: 231-241.

Lampitt, R.S., K.E. Wishner, C.M. Turley and M.V. Angel. - 1993. Marine snow studies in the Northeast Atlantic ocean: distribution, composition and role as a food source for migrating plankton. Mar. Biol., 116: 689-702.

Le Fevre-Lehoerff, G., F. Ibanez, P. Poniz and J.M. Fromentin. 1995. Hydroclimatic relationships with planktonic time series from 1975 to 1992 in the North Sea off Gravelines, France. Mar. Ecol. Prog. Ser., 129: 269-281.

Lenzi Grillini, C. and L. Lazzara. - 1978. Ciclo annuale del fitoplancton nelle acque costiere del Parco Naturale della Maremma. I. Variazioni quantitative. G. Bot. Ital., 112: 157-173.

Licandro, P. and F. Ibanez - 2000. Changes of zooplankton communities in the Gulf of Tigullio (Ligurian Sea, Western Mediterranean) from 1985 to 1995 . Influence of hydroclimatic factors. J. Plankton Res., 22: 2225-2253.

Longhurst, A. - 1998. Ecological Geography of the Sea. Academic Press, San Diego, CA.

Lovegrove, T. - 1966. The determination of the dry weight of plankton and effect of various factors on the values obtained. In: H. Barnes (ed.), Some contemporary studies in marine science, pp. 429-467. G. Allen and Unwin, London.

López, S., X. Turón, E. Montero, C. Palacín, C.M. Duarte and I. Tarjuelo. - 1998. Larval abundance, recruitment and early mortality in Paracentrotus lividus (Echinoidea). Interannual variability and plankton-benthos coupling. Mar. Ecol. Prog. Ser., 172: $239-251$

Mangoni, O. - 1999. I pigmenti fotosintetici del fitoplancton nell'ambito dei processi di produzione primaria in diversi contesti ecologici, Ph.D. thesis, Univ. Messina.

Mann, K.H. and J.R.N. Lazier - 1996. Dynamics of marine ecosystems. Biological-physical interactions in the oceans. Blackwell Science, Oxford.

Margalef, R. - 1969. Small scale distribution of phytoplankton in western Mediterranean at the end of July. Pubb. Staz. Zool. Napoli, 37(Suppl.): 40-61.

Margalef, R. - 1978. Life-forms of phytoplankton as survival alternatives in an unstable environment. Oceanol. Acta, 1: 493-509.

Margalef, R. - 1997. Turbulence and marine life. Sci. Mar., 61: 109-123.

Margalef, R. and D. Blasco. - 1970. Influencia del puerto de Barcelona sobre el fitoplancton de las áreas vecinas. Una mancha de plancton de gran densidad, con dominancia de Thalassiosira, observada en agosto de 1969. Inv. Pesq., 34: 575-580.

Margalef, R. and J. Castellví - 1967. Fitoplancton y producción primaria de la costa catalana, de julio de 1966 a julio de 1967. Inv. Pesq., 31: 491-502.

Marino, D., M. Modigh and A. Zingone. - 1984. General features of phytoplankton communities and primary production in the Gulf of Naples and adjacent waters. In: O. Holm-Hansen, L. Bolis and R. Gilles (eds.), Marine phytoplankton and produc- 
tivity, pp. 89-100. Springer, Berlin.

Mazzocchi, M.G. and G.-A. Paffenhöfer. - 1998. First observations on the biology of Clausocalanus furcatus (Copepoda: Calanoida). J. Plankton Res., 20: 331-342.

Mazzocchi, M.G. and G.-A. Paffenhöfer. - 1999. Swimming and feeding behaviour of the planktonic copepod Clausocalanus furcatus. J. Plankton Res., 21: 1501-1518.

Mazzocchi, M.G. and M. Ribera d'Alcalà. - 1995. Recurrent patterns in zooplankton structure and succession in a variable coastal environment. ICES J. Mar. Sci., 52: 679-691.

Ménard, F., S. Dallot, G. Thomas and J.C. Braconnot. - 1994. Temporal fluctuations of two Mediterranean salp populations from 1967 to 1990. Analysis of the influence of environmental variables using a Markov chain model. Mar. Ecol. Prog. Ser., 104: 139-152.

Ménard, F., J.-M. Fromentin, J. Goy and S. Dallot. - 1997. Temporal fluctuations of doliolid abundance in the bay of Villefranche-sur-Mer (Northwestern Mediterranean Sea) from 1967 to 1990. Oceanol. Acta, 20: 733-742.

Modigh, M. - 2001. Seasonal variations of photosynthetic ciliates at a Mediterranean coastal site. Aquat. Microb. Ecol., 23: 163-175.

Modigh, M. and S. Castaldo - 2002. Variability and persistence in tintinnid populations at a Mediterranean coastal site. Aquat. Microb. Ecol. 28: 299-311.

Modigh, M., M. Ribera d'Alcalà, V. Saggiomo, G. Forlani and E. Tosti. - 1985. Time relationship between physical-chemical and biological properties of phytoplankton blooms in the inner part of the Gulf of Naples, summer 1983. Rapp. Comm. Int. Mer Médit., 29: 109-110.

Modigh, M., V. Saggiomo and M. Ribera d'Alcalà. - 1996. Conservative features of picoplankton in a Mediterranean eutrophic area, the Bay of Naples. J. Plankton Res., 18: 87-95.

Montresor, M., A. Zingone and D. Sarno. - 1998. Dinoflagellate cyst production at a coastal Mediterranean site. J. Plankton Res., 20: 2291-2312.

Mozetić, P., S. Fonda Umani, B. Cataletto and A. Malej. - 1998. Seasonal and inter-annual plankton variability in the Gulf of Trieste (northern Adriatic). ICES J. Mar. Sci., 55: 711-722.

Mura, M.P., S. Agustí, J. Cebrián and M.P. Satta. - 1996. Seasonal variability of phytoplankton biomass and community composition in Blanes Bay (1992-1994). Publ. Espec. Inst. Esp. Oceanogr., 22: 23-29.

Neveux, J. and M. Panouse. - 1987. Spectrofluorometric determination of chlorophylls and pheophytins. Arch. Hydrobiol., 109: 567-581.

Ohtsuka, S., R. Böttger-Schnack, M. Okada and T. Onbé. - 1996. In situ feeding habits of Oncaea (Copepoda: Poecilostomatoida) from the upper $250 \mathrm{~m}$ of the central Red Sea, with special reference to consumption of appendicularian houses. Bull. Plankton Soc. Jap., 43: 89-105.

Paffenhöfer, G.-A. - 1973. The cultivation of an appendicularians through numerous generations. Mar. Biol., 22: 183-185.

Paffenhöfer, G.-A. - 1998. On the relation of structure, perception and activity in marine planktonic copepods. J. Mar. Sys., 15: 457-473.

Paffenhöfer, G.-A. and M.G. Mazzocchi - 2002. On some aspects of the behaviour of Oithona plumifera (Copepoda: Cyclopoida). J. Plankton Res., 24: 129-135.

Paffenhöfer, G.-A. and J.D.J. Orcutt. - 1986. Feeding, growth and food conversion of the marine cladoceran Penilia avirostris. $J$. Plankton Res., 8: 741-754

Platt, T., J.D. Woods, S. Sathyendranath and W. Barkmann. - 1994. Net primary production and stratification in the ocean. In: D.M. Johannesen, R.D. Muench and D.E. Overland (eds.), The Polar oceans and their role in shaping the global environment, pp. 247-254. American Geophysical Union, Washington.

Psarra, S., A. Tselepides and L. Ignatiades . - 2000. Primary productivity in the oligotrophic Cretan Sea (NE Mediterranean): seasonal and interannual variability. Prog. Oceanogr., 46: 187-204.

Pucher-Petković, T. and I. Marasović. - 1980. Developpment des populations phytoplanctoniques caracteristiques pour un milieu eutrophisé (Baie de Ka_tela, Adriatique centrale). Acta Adriat., 21: 79-93.

Putt, M. and D.K. Stoecker. - 1989. An experimentally determined carbon:volume ratio for marine 'oligotrichous' ciliates from estuarine and coastal waters. Limnol. Oceanogr., 34: 1097-1103.

Ragueneau, O., P. Treguer, A. Leynaert, R.F. Anderson, M.A. Brzezinski, D.J. DeMaster, R.C. Dugdale, J. Dymond, G. Fis- cher, R. Francois, C. Heinze, E. Maier-Reimer, V. Martin-Jezequel, D.M. Nelson and B. Queguiner - 2000. A review of the Si cycle in the modern ocean: recent progress and missing gaps in the application of biogenic opal as a paleoproductivity proxy. Global Planet. Change, 26: 317-365.

Redden, A.M. - 1994. Grazer-mediated chloropigment degradation and the vertical flux of spring bloom production in Conception Bay. Ph. D. thesis, St Johns, Memorial Univ. of Newfoundland.

Reynolds, C.S. - 1993. Scales of disturbance and their role in plankton ecology. Hydrobiologia, 249: 157-171.

Reynolds, C.S., J. Padisak and U. Sommer. - 1993. Intermediate disturbance in the ecology of phytoplankton and the maintenance of species diversity: a synthesis. Hydrobiologia, 249: 183-188.

Reynolds, C.S. and T.J. Smayda. - 1998. Principles of species selection and community assembly in the phytoplankton: further explorations of the Mandala. In: B. Reguera, J. Blanco, M.L. Fernández and T. Wyatt (eds.), Harmful Algae, pp. 8-10. Xunta de Galicia and IOC-UNESCO, Santiago De Compostela.

Ribera d'Alcalà, M., M. Modigh, M. Moretti, V. Saggiomo, M. Scardi, G. Spezie and A. Zingone. - 1989. Una storia infinita. Eutrofizzazione nella Baia di Napoli. Oebalia, 15:491-501.

Ribera d'Alcalà, M., V. Saggiomo and G. Civitarese. - 1997 Nutrients in the sea. In: A. Gianguzza, E. Pelizzetti and S. Sammartano (eds.), Marine Chemistry. An environmental marine chemistry approach, pp. 99-114. Kluwer Academic, The Netherlands.

Romeo, A.J. and N.S. Fisher - 1982. Intraspecific comparisons of nitrate uptake in three marine diatoms. J. Phycol., 18: 220-225.

Saiz, E., V. Rodríguez and M. Alcaraz. - 1992. Spatial distribution and feeding rates of Centropages typicus in relation to frontal hydrographic structures in the Catalan Sea (Western Mediterranean). Mar. Biol., 112: 49-56.

Scotto di Carlo, B., C.R. Tomas, A. Ianora, D. Marino, M.G. Mazzocchi, M. Modigh, M. Montresor, L. Petrillo, M. Ribera d'Alcalà, V. Saggiomo and A. Zingone. - 1985. Uno studio integrato dell'ecosistema pelagico costiero del Golfo di Napoli. Nova Thalassia, 7: 99-128.

Shiganova, T.A. - 1998. Invasion of the Black Sea by the ctenophore Mnemiopsis leidyi and recent changes in pelagic community structure. Fish. Oceanogr., 7: 305-310.

Siokou-Frangou, I. - 1996. Zooplankton annual cycle in a Mediterranean coastal area. J. Plankton Res., 18:203-223.

Siokou-Frangou, I., E.D. Christou, N. Fragopoulu and M.G. Mazzocchi. - 1997. Mesozooplankton distribution from Sicily to Cyprus (Eastern Mediterranean): II. Copepod assemblages. Oceanol. Acta, 20:537-548.

Smayda, T.J. - 1957. Phytoplankton studies in lower Narragansett Bay. Limnol. Oceanogr., 2: 342-359.

Smayda, T.J. - 1970. The suspension and sinking of phytoplankton in the sea. Oceanogr. Mar. Biol. Ann. Rev., 8: 353-414.

Smayda, T. - 1980. Phytoplankton species succession. In: I. Morris (ed.), The physiological ecology of phytoplankton, pp. 493570. Blackwell Scientific Publications, Oxford

Smetacek, V. and U. Passow. - 1990. Spring bloom initiation and Sverdrup's critical-depth model. Limnol. Oceanogr., 35: 228-234.

Sournia, A. and J.L. Birrien. - 1995. La série océanographique cotière de Roscoff (Manche occidentale) de 1985 à 1992. Cah. Biol. Mar., 36: 1-8.

Southward, A.J. - 1995. The importance of long time-series in understanding the variability of natural systems. Helgolander Meeresunters., 49: 329-333.

Strathmann, R.R. - 1967. Estimating the organic carbon content of phytoplankton from cell volume or plasma volume. Limnol. Oceanogr., 12: 411-418.

Strickland, J.D.H. and T.R. Parsons - 1972. A practical handbook of sea water analysis. Bull. Fish. Res. Bd. Canada, 167: 1-310.

Suzuki, K., Y. Nakamura and J. Hiromi. - 1999. Feeding by the small calanoid copepod Paracalanus sp. on heterotrophic dinoflagellates and ciliates. Aquat. Microb. Ecol., 17: 99-103.

Svensen, C. and T. Kiørboe. - 2000. Remote prey detection in Oithona similis: hydromechanical versus chemical cues. $J$. Plankton Res., 22: 1155-1166.

Sverdrup, H.U. - 1953. On conditions for the vernal blooming of phytoplankton. J. Cons. Perm. Iint. Explor. Mer, 18: 287-295.

Thiriot, A. - 1972-73. Les cladocères de Méditerranée Occidentale. III. - Cycle et répartition à Banyuls-sur-Mer (Golfe du Lion). Synthèse des années 1965-1969. Vie Milieu, 23: 243-295. 
Tiselius, P. - 1989. Contribution of aloricate ciliates to the diet of Acartia clausi and Centropages hamatus in coastal waters. Mar. Ecol. Prog. Ser., 56: 49-56.

Townsend, D. and L. Cammen. - 1988. Potential importance of the timing of spring plankton blooms to benthic-pelagic coupling and recruitment of juvenile demersal fishes. Biol. Oceanogr., 5: 215-229.

Townsend, D.W., L.M. Cammen, P.M. Holligan, D.E. Campbell and N.R. Pettigrew. - 1994. Causes and consequences of variability in the timing of spring phytoplankton blooms. Deep-Sea Res., 41: 747-765.

Townsend, D., D. Keller, M. Sieracki and S. Ackleson. - 1992 Spring phytoplankton blooms in the absence of vertical water column stratification. Nature, 360: 59-62.

Travers, M. - 1974. Inventaire des protistes du Golfe de Marseille et de ses parages. Ann. Inst. Oceanogr. Paris, 51: 51-75.

Turner, J.T., P.A. Tester and R.L. Ferguson. - 1988. The marine cladoceran Penilia avirostris and the 'microbial loop' of pelagic food webs. Limnol. Oceanogr., 33: 245-255.

Uchima, M. and R. Hirano. - 1988. Swimming behavior of the marine copepod Oithona davisae: internal control and search for environment. Mar. Biol., 99: 47-56.

Utermöhl, H. - 1958. Zur Vervollkommnung der quantitativen Phytoplankton-Methodik. Mitt. Int. Ver. Theor. Angew. Limnol., 9: 1-38

Walsby, A.F. and C.S. Reynolds - 1980. Sinking and floating. In: I. Morris (ed.), The physiological ecology of phytoplankton, pp. 371-412. Blackwell Scientific Publications, Oxford.

Zingone, A., R. Casotti, M. Ribera d'Alcalà, M. Scardi and D. Marino. - 1995. 'St Martin's Summer': the case of an autumn phytoplankton bloom in the Gulf of Naples (Mediterranean Sea). J. Plankton Res., 17: 575-593.

Zingone, A., M. Montresor and D. Marino. - 1990. Summer phytoplankton physiognomy in coastal water of the Gulf of Naples. P.S.Z.N.I: Mar. Ecol., 11: 157-172.

Zingone, A. and D. Sarno - 2001. Recurrent patterns in coastal phytoplankton from the Gulf of Naples. Arch. Oceanogr. Limnol., 22: 113-118.

Zupo, V. and M.G. Mazzocchi. - 1998. New perspectives in the investigation of food webs in benthic and planktonic coastal ecosystems. Biol. Mar. Medit., 5: 12-26. 
